\title{
ANALISIS TINGKAT BAHAYA LONGSOR PADA JALAN NASIONAL UNTUK PRIORITAS PENANGANAN DENGAN METODE AHP: STUDI KASUS JALAN PADA SATKER PJN III DAN PJN IV
}

\author{
Maulidi Al Kahfi \\ Universitas Sumatera Utara (USU), Indonesia \\ Email: maulidialkahfi@yahoo.com
}

\begin{abstract}
Abstrak
Bencana longsor menjadi ancaman yang sangat berbahaya terhadap stabilitas badan jalan, sehingga penanganan yang baik sangat diperlukan untuk mengatasi permasalahan longsoran agar luas longsor yang telah terjadi tidak semakin melebar. Karena jumlah titik longsor pada Jalan Nasional cukup banyak maka diperlukan kegiatan preservasi dengan melakukan langkah prioritisasi penanganan longsoran jalan. Lokasi penelitian adalah Jalan Nasional Provinsi Sumatera Utara yang berada pada area Satker PJN III (Satuan Kerja Pelaksanaan Jalan Nasional III) dan Satker PJN IV (Satuan Kerja Pelaksanaan Jalan Nasional IV). Terdapat 26 ruas jalan pada area Satker PJN III dan Satker PJN IV, dengan 34 titik longsor yang terjadi. Prioritisasi penanganan longsoran jalan pada penelitian ini menggunakan metode AHP (Analytical Hierarchy Proses) dengan dua tahapan. Tahap pertama adalah menganalisis tingkat bahaya longsor yang terjadi pada jalan, sedangkan tahap kedua adalah menentukan tingkat prioritas penanganan longsor pada masingmasing titik longsor di ruas jalan tersebut. Parameter yang digunakan dalam menentukan tingkat bahaya longsor yaitu kemiringan tanah, tutupan lahan, curah hujan, tanah dasar, kondisi drainase. Sementara untuk menentukan tingkat prioritas penanganan digunakan parameter bahaya longsor, dimensi longsor, rekayasa lereng dan lalulintas harian rata-rata.
\end{abstract}

Kata Kunci: AHP; jalan nasional; longsor; prioritas

\section{Abstract}

Landslides are a very dangerous threat to the roads. Good management is required to prevent the problems occurring from extensive possible landslides. This is because the number of potential landslide points on the National roads are numerous. Maintenance and prevention are crucial to keep these disasters from occurring. Therefore these need to be a priority. The locations in question are: The National Road in the Provence of North Sumatra, the area of Satker PJN Ill (Satuan Kerja Pelaksanaan Jalan Nasional III) and The Satker PJN IV (Satuan Kerja Pelaksanaan Jalan Nasional IV). There are 26 roads in the Satker PJN III and IV areas with 34 that have occurred. The method that is used in this study is the AHP (Analytical Hierarchy Process). Method using two stages: The first stage is to analyze the level of landslide hazard on the road. The second stage is to determine the priority level for the handling of each landslide point for each section of the road. The parameters used determining the level of landslide hazard are: 
Analisis Tingkat Bahaya Longsor pada Jalan Nasional untuk Prioritas Penanganan dengan Metode AHP: Studi Kasus Jalan pada Satker PJN III dan PJN IV

Soil, slope, landcover, rainfall, subgrade and drainage conditions, at the same time as using the landslide hazard perimeters, landslide dimensions, slope engineering and every day traffic.

Keywords: AHP; National Road; Landslide; Priority

Received: 2021-11-22; Accepted: 2021-12-05; Published: 2021-12-20

\section{Pendahuluan}

Jalan yang merupakan salah satu prasarana transportasi memegang peranan penting dalam mendukung pengembangan wilayah, pembangunan ekonomi, mobilitas manusia, barang dan jasa (Srianty, Isya, \& Anggraini, 2017). Oleh karena itu peningkatan kinerja jalan perlu dilakukan dengan cara meningkatkan kualitas dan kapasitas jalan yang belum mantap dan mempertahankan kondisi jalan yang sudah mantap agar waktu tempuh rata-rata kendaraan menjadi semakin singkat (Udiana, Saudale, \& Pah, 2014). Ancaman bencana alam dan stabilitas badan jalan di daerah rawan longsor merupakan suatu masalah yang dapat mengakibatkan kerusakan badan jalan dan bahkan terputusnya badan jalan secara tiba-tiba. Sementara teknis penanganan badan jalan akibat bencana alam dan/atau penanggulangan longsoran badan jalan, dengan tujuan agar jalan cepat berfungsi, pada umumnya ditangani secara darurat atau sementara (Jagad, Mulyono, \& Santosa, 2020).

Longsor saat ini menajdi bencana yang cukup sering terjadi di Indonesia. Hal ini dikarenakan curah hujan yang cukup tinggi dan gempa yang sering terjadi di Indonesia. Pada 23 Februari 2010 bencana longsor terjadi di Bandung (Putra \& Triyono, 2018), longsor Sukabumi pada 31 Desember 2018 (Putra \& Triyono, 2018), longsor di Kabupaten Agam pada 3 Juni 2020 (Tagar.id - 2020), hingga longsor yang terbaru terjadi di Sumedang pada 9 Januari 2021 (Harefa, Ginting, Sitorus, \& Nababan, 2021), mengakibatkan akses jalan terputus. Provinsi Sumatera Utara juga tidak luput dari bencana longsor, pada 30 Januari terjadi dua bencana longsor di Kabupaten Paluta yang menyebabkan akses jalan dan jembatan rusak dan terputus (Hasan et al., 2021). Pada 11 Juli 2020 bencana longsor juga terjadi di Kabupaten Simalungun dan Deli Serdang akibat curah hujan yang tinggi (Damanik, 2019). Badan Nasional Penanggulangan Bencana (BNPB) mencatat setidaknya 27 Kabupaten di Provinsi Sumatera Utara memiliki potensi bahaya tanah longsor dengan tingkat bahaya sedang dan tinggi (Fasa, 2019).

Untuk menghindari terjadi lumpuhnya pelayanan transportasi secara tiba-tiba, maka penanganan sementara harus diganti dengan penanganan secara permanen, agar daerah rawan longsor tidak berakumulasi (Jagad et al., 2020). Dari tahun ke tahun daerah rawan longsor akan semakin banyak, mengingat longsoran lama akan tetap menjadi daerah rawan longsor sedangkan longsoran yang baru selalu bertambah. Untuk melaksanakan penanggulangan longsoran yang bersifat permanen, maka penyelidikan diperlukan untuk menganalisis dan merencanakan teknik yang matang dan tepat, guna 
menghasilkan suatu metoda penanganan longsoran yang optimal, efisien dan berwawasan lingkungan serta dapat diaplikasikan di lapangan (Nur \& NIP, 2007).

Mengingat biaya yang terbatas maka prioritisasi dibutuhkan dalam menentukan daerah rawan longsor yang akan ditangani secara permanen (Sulamet-Ariobimo et al., 2020). Prioritisasi dalam penanggulangan daerah rawan longsor adalah sebuah proses yang dibutuhkan untuk mendapatkan tingkat prioritas penanganan dengan sistem ranking yang didasarkan pada penilaian kriteria tertentu yang mempengaruhi kerawanan longsor. Proses prioritisasi dapat dilakukan menggunakan metode AHP (Analytical Hierarchy Proses).

Dalam penelitian ini perumusan masalahnya adalah bagaimana memberikan skala prioritas dalam penanganan daerah rawan longsor dengan mengevaluasi faktor-faktor yang mempengaruhi tingkat kerawanan longsor yang dapat menentukan tingkat kerusakan jalan di setiap lokasi. Hasil penelitian ini diharapkan dapat menjadi masukan dan pertimbangan dalam rencana penanganan daerah rawan longsor secara permanen.

\section{Metode Penelitian}

Penelitian ini menggunakan metode AHP yang merupakan suatu metode pengambilan keputusan yang dikembangkan oleh Thomas L. Saaty, dan merupakan metode untuk membuat urutan alternatif keputusan dan pemilihan alternatif terbaik pada saat pengambil keputusan dengan beberapa tujuan atau kriteria untuk mengambil keputusan tertentu. Metode pengambilan keputusan ini akan mengurai masalah multi faktor atau multi kriteria yang kompleks menjadi suatu hierarki. Prinsip kerja AHP adalah menyederhanakan suatu masalah kompleks menjadi bagian-bagiannya dan menatanya dalam suatu hirarki atau peringkat. Input awal untuk matriks perbandingan dalam metode ini digunakan dengan menentukan skor masing-masing faktor yang digunakan (Lasera, M., Mudin, Y., Rusydi, 2016). Metode AHP membantu memecahkan persoalan yang kompleks dengan menstrukturkan suatu hierarki kriteria, pihak yang berkepentingan, hasil dan dengan menarik berbagai pertimbangan guna mengembangkan bobot atau prioritas. Hierarki didefinisikan sebagai suatu representasi dari sebuah permasalahan yang kompleks dalam suatu struktur multilevel dimana level pertama adalah tujuan, yang diikuti level faktor, kriteria, sub kriteria, dan seterusnya hingga level terakhir dari alternatif (Fatmawati, Windarto, Solikhun, \& Lubis, 2017).

Metode AHP digunakan dalam penelitian ini dengan alasan struktur hierarki yang memiliki konsekuensi dari kriteria yang dipilih, sampai pada sub kriteria yang paling dalam serta perhitungan validasi sampai dengan batas toleransi inkonsistensi sebagai kriteria dan alternatif yang dipilih oleh pengambil keputusan.

\section{Hasil dan Pembahasan}

Hasil pengumpulan data primer dan sekunder yang telah diperoleh menunjukkan 14 ruas Jalan Nasional di Provinsi Sumatera Utara khususnya pada area Satker PJN III dan Satker PJN IV yang telah mengalami bencana longsor. Ruas jalan yang terdampak bencana longsor dapat diberi kode ruas sebagai berikut: 
1. Batas Kota Medan - Batas Kab. Karo (MK)

2. Merek - Batas Kab. Dairi (MD)

3. Tiga Rungu - Tanjung Dolok (RD)

4. Jln. Kutacane - Batas Kota Kabanjahe - Kuta Buluh (KK)

5. Kuta Buluh - Batas Kota Sidikalang (KS)

6. Barus - Batas Kota Sibolga (BS)

7. Rampa - Poriaha/Mungkur (RP)

8. Batas Kota Tarutung - Batas Kab. Tapanuli Tengah (TT)

9. Batas Kab Tapanuli Utara - Batas Kota Sibolga (TS)

10.Batang Toru - Sp. Aek Rambe (BA)

11.Sp. Aek Rambe - Singkuang (AS)

12.Tetehosi - Lahusa (TL)

13.Lahusa - Teluk Dalam (LT)

14.Teluk Dalam - Lolowau (TDL)

Dari 14 ruas jalan yang terdampak bencana longsor ditemukan 34 titik longsor yang terjadi pada ruas jalan tersebut. Sebagian besar lokasi longsor yang terjadi berada pada jalan dengan kondisi drainase yang kurang baik, sehingga air permukaan tidak dapat dikendalikan. Kondisi ini menyebabkan tanah menjadi jenuh dan tidak stabil sehingga tanah mudah untuk runtuh. Deskripsi data tersebut dapat dilihat pada Tabel 1.

Tabel 1

Kondisi Ruas Jalan di 14 Lokasi Longsor

\begin{tabular}{|c|c|c|c|c|c|c|c|c|c|}
\hline No & Ruas & $\begin{array}{c}\text { Kemiringan } \\
\text { Tanah }\end{array}$ & $\begin{array}{c}\text { Tutupan } \\
\text { Lahan }\end{array}$ & $\begin{array}{l}\text { Curah } \\
\text { Hujan }\end{array}$ & $\begin{array}{l}\text { Tanah } \\
\text { Dasar }\end{array}$ & $\begin{array}{c}\text { Kondisi } \\
\text { Drainase }\end{array}$ & $\begin{array}{l}\text { Dimensi } \\
\text { Longsor }\end{array}$ & $\begin{array}{c}\text { Lalulintas } \\
\text { Harian }\end{array}$ & $\begin{array}{c}\text { Rekayasa } \\
\text { Lereng }\end{array}$ \\
\hline 1 & $\begin{array}{l}\text { Bts. Kota Medan } \\
- \text { Bts. Kab. Karo } \\
\text { (Sta } 010+250)\end{array}$ & $45^{\circ}$ & Kebun & 1656 & $\begin{array}{l}\text { Tidak } \\
\text { Stabil }\end{array}$ & $\begin{array}{l}\text { Tidak } \\
\text { Ada }\end{array}$ & $223 \mathrm{~m}^{2}$ & 14278 & Efektif \\
\hline 2 & $\begin{array}{l}\text { Bts. Kota Medan } \\
\text { - Bts. Kab. Karo } \\
\text { (Sta 021+950) }\end{array}$ & $55^{\circ}$ & Hutan & 1656 & Stabil & $\begin{array}{l}\text { Tidak } \\
\text { Ada }\end{array}$ & $200 \mathrm{~m}^{2}$ & 14278 & Efektif \\
\hline 3 & $\begin{array}{ll}\text { Merek } \quad- & \text { Bts. } \\
\text { Kab. Dairi } & \text { (Sta } \\
099+100) & \end{array}$ & $55^{\circ}$ & Hutan & 1625 & $\begin{array}{l}\text { Tidak } \\
\text { Stabil }\end{array}$ & $\begin{array}{l}\text { Tidak } \\
\text { Berfungsi }\end{array}$ & $600 \mathrm{~m}^{2}$ & 7233 & $\begin{array}{l}\text { Tidak } \\
\text { Efektif }\end{array}$ \\
\hline 4 & $\begin{array}{ll}\text { Merek }- & \text { Bts. } \\
\text { Kab. Dairi } & \text { (Sta } \\
099+100) & \end{array}$ & $42.5^{\circ}$ & Hutan & 1625 & $\begin{array}{l}\text { Tidak } \\
\text { Stabil }\end{array}$ & $\begin{array}{l}\text { Tidak } \\
\text { Berfungsi }\end{array}$ & $624 \mathrm{~m}^{2}$ & 7233 & $\begin{array}{l}\text { Tidak } \\
\text { Efektif }\end{array}$ \\
\hline 5 & $\begin{array}{l}\text { Tiga Rungu - } \\
\text { Tanjung Dolok } \\
(\text { Sta } 125+310)\end{array}$ & $33^{\circ}$ & Hutan & 3517 & $\begin{array}{l}\text { Tidak } \\
\text { Stabil }\end{array}$ & $\begin{array}{l}\text { Berfungsi } \\
\text { Sebagian }\end{array}$ & $215 \mathrm{~m}^{2}$ & 3881 & $\begin{array}{l}\text { Tidak } \\
\text { Efektif }\end{array}$ \\
\hline 6 & $\begin{array}{l}\text { Jln. Kutacane - } \\
\text { Bts. Kota } \\
\text { Kabanjahe } \quad- \\
\text { Kuta Buluh (Sta. } \\
049+550)\end{array}$ & $45^{\circ}$ & Kebun & 1615 & $\begin{array}{l}\text { Tidak } \\
\text { Pasti }\end{array}$ & Optimal & $90 \mathrm{~m}^{2}$ & 3153 & $\begin{array}{l}\text { Tidak } \\
\text { Efektif }\end{array}$ \\
\hline 7 & $\begin{array}{lr}\text { Jln. } & \text { Kutacane }- \\
\text { Bts. } & \text { Kota } \\
\text { Kabanjahe } & -\end{array}$ & $45^{\circ}$ & Kebun & 1615 & $\begin{array}{l}\text { Tidak } \\
\text { Stabil }\end{array}$ & $\begin{array}{l}\text { Tidak } \\
\text { Berfungsi }\end{array}$ & $750 \mathrm{~m}^{2}$ & 3153 & $\begin{array}{l}\text { Tidak } \\
\text { Efektif }\end{array}$ \\
\hline
\end{tabular}




\begin{tabular}{|c|c|c|c|c|c|c|c|c|c|}
\hline No & Ruas & $\begin{array}{c}\text { Kemiringan } \\
\text { Tanah }\end{array}$ & $\begin{array}{c}\text { Tutupan } \\
\text { Lahan }\end{array}$ & $\begin{array}{l}\text { Curah } \\
\text { Hujan }\end{array}$ & $\begin{array}{l}\text { Tanah } \\
\text { Dasar }\end{array}$ & $\begin{array}{c}\text { Kondisi } \\
\text { Drainase }\end{array}$ & $\begin{array}{l}\text { Dimensi } \\
\text { Longsor }\end{array}$ & $\begin{array}{c}\text { Lalulintas } \\
\text { Harian }\end{array}$ & $\begin{array}{c}\text { Rekayasa } \\
\text { Lereng }\end{array}$ \\
\hline & $\begin{array}{l}\text { Kuta Buluh (Sta. } \\
050+450)\end{array}$ & & & & & & & & \\
\hline 8 & $\begin{array}{lr}\text { Jln. Kutacane }- \\
\text { Bts. Kota } \\
\text { Kabanjahe r } \\
\text { Kuta Buluh (Sta. } \\
050+450)\end{array}$ & $60^{\circ}$ & Kebun & 1615 & $\begin{array}{l}\text { Tidak } \\
\text { Stabil }\end{array}$ & $\begin{array}{l}\text { Tidak } \\
\text { Berfungsi }\end{array}$ & $180 \mathrm{~m}^{2}$ & 3153 & $\begin{array}{l}\text { Tidak } \\
\text { Efektif }\end{array}$ \\
\hline 9 & $\begin{array}{lc}\text { Kuta Buluh }- \\
\text { Bts. } & \text { Kota } \\
\text { Sidikalang } & \text { (Sta. } \\
018+040) & \\
\end{array}$ & $40^{\circ}$ & Semak & 1384 & $\begin{array}{l}\text { Tidak } \\
\text { Stabil }\end{array}$ & $\begin{array}{l}\text { Tidak } \\
\text { Ada }\end{array}$ & $345 \mathrm{~m}^{2}$ & 2530 & $\begin{array}{l}\text { Tidak } \\
\text { Efektif }\end{array}$ \\
\hline 10 & $\begin{array}{lc}\text { Kuta Buluh }- \\
\text { Bts. } & \text { Kota } \\
\text { Sidikalang } & \text { (Sta. } \\
028+375) & \\
\end{array}$ & $40^{\circ}$ & Semak & 1384 & $\begin{array}{l}\text { Tidak } \\
\text { Stabil }\end{array}$ & $\begin{array}{l}\text { Tidak } \\
\text { Ada }\end{array}$ & $750 \mathrm{~m}^{2}$ & 2530 & $\begin{array}{l}\text { Tidak } \\
\text { Efektif }\end{array}$ \\
\hline 11 & $\begin{array}{lc}\text { Kuta Buluh }- \\
\text { Bts. } & \text { Kota } \\
\text { Sidikalang } & \text { (Sta. } \\
033+110) & \\
\end{array}$ & $55^{\circ}$ & Hutan & 1384 & $\begin{array}{l}\text { Tidak } \\
\text { Pasti }\end{array}$ & Optimal & $940 \mathrm{~m}^{2}$ & 2530 & $\begin{array}{l}\text { Sebagian } \\
\text { Efektif }\end{array}$ \\
\hline 12 & $\begin{array}{ll}\text { Barus - Bts. Kota } \\
\text { Sibolga } \\
010+515)\end{array}$ & $20^{\circ}$ & Kebun & 2204 & $\begin{array}{l}\text { Tidak } \\
\text { Stabil }\end{array}$ & $\begin{array}{l}\text { Berfungsi } \\
\text { Sebagian }\end{array}$ & $210 \mathrm{~m}^{2}$ & 917 & $\begin{array}{l}\text { Sebagian } \\
\text { Efektif }\end{array}$ \\
\hline 13 & $\begin{array}{l}\text { Rampa - } \\
\text { Poriaha/Mungkur } \\
(\text { Sta. 007+000) }\end{array}$ & $90^{\circ}$ & Hutan & 3324 & $\begin{array}{l}\text { Tidak } \\
\text { Stabil }\end{array}$ & $\begin{array}{l}\text { Tidak } \\
\text { Berfungsi }\end{array}$ & $240 \mathrm{~m}^{2}$ & 254 & $\begin{array}{l}\text { Tidak } \\
\text { Efektif }\end{array}$ \\
\hline 14 & $\begin{array}{l}\text { Rampa }- \\
\text { Poriaha/Mungkur } \\
\text { (Sta. 007+000) }\end{array}$ & $40^{\circ}$ & Hutan & 3324 & $\begin{array}{l}\text { Tidak } \\
\text { Stabil }\end{array}$ & $\begin{array}{l}\text { Tidak } \\
\text { Berfungsi }\end{array}$ & $425 \mathrm{~m}^{2}$ & 254 & $\begin{array}{l}\text { Tidak } \\
\text { Efektif }\end{array}$ \\
\hline 15 & $\begin{array}{lr}\text { Bts. } & \text { Kota } \\
\text { Tarutung } & - \text { Bts. } \\
\text { Kab. Tapanuli } \\
\text { Tengah } \quad \text { Sta. } \\
023+580) & \\
\end{array}$ & $60^{\circ}$ & Semak & 2724 & $\begin{array}{l}\text { Tidak } \\
\text { Stabil }\end{array}$ & $\begin{array}{l}\text { Tidak } \\
\text { Berfungsi }\end{array}$ & $215 \mathrm{~m}^{2}$ & 1679 & $\begin{array}{l}\text { Tidak } \\
\text { Efektif }\end{array}$ \\
\hline 16 & $\begin{array}{lr}\text { Bts. } & \text { Kota } \\
\text { Tarutung } & - \text { Bts. } \\
\text { Kab. Tapanuli } \\
\text { Tengah } \quad \text { (Sta. } \\
030+400)\end{array}$ & $20^{\circ}$ & Kebun & 2724 & $\begin{array}{l}\text { Tidak } \\
\text { Stabil }\end{array}$ & Optimal & $150 \mathrm{~m}^{2}$ & 1679 & $\begin{array}{l}\text { Sebagian } \\
\text { Efektif }\end{array}$ \\
\hline 17 & $\begin{array}{lr}\text { Bts. } & \text { Kota } \\
\text { Tarutung } & - \text { Bts. } \\
\text { Kab. Tapanuli } \\
\text { Tengah } \quad \text { (Sta. } \\
\text { 032+680) }\end{array}$ & $40^{\circ}$ & Semak & 2724 & $\begin{array}{l}\text { Tidak } \\
\text { Stabil }\end{array}$ & $\begin{array}{l}\text { Tidak } \\
\text { Berfungsi }\end{array}$ & $130 \mathrm{~m}^{2}$ & 1679 & $\begin{array}{l}\text { Tidak } \\
\text { Efektif }\end{array}$ \\
\hline 18 & $\begin{array}{lr}\text { Bts. } & \text { Kota } \\
\text { Tarutung } & - \text { Bts. } \\
\text { Kab. Tapanuli } \\
\text { Tengah } \quad \text { (Sta. } \\
045+100)\end{array}$ & $27^{\circ}$ & Hutan & 2724 & $\begin{array}{l}\text { Tidak } \\
\text { Pasti }\end{array}$ & Optimal & $180 \mathrm{~m}^{2}$ & 1679 & $\begin{array}{l}\text { Sebagian } \\
\text { Efektif }\end{array}$ \\
\hline 19 & $\begin{array}{lr}\text { Bts. } & \text { Kab } \\
\text { Tapanuli Utara } & -\end{array}$ & $45^{\circ}$ & Semak & 3324 & $\begin{array}{l}\text { Tidak } \\
\text { Stabil }\end{array}$ & $\begin{array}{l}\text { Tidak } \\
\text { Berfungsi }\end{array}$ & $525 \mathrm{~m}^{2}$ & 1441 & $\begin{array}{l}\text { Tidak } \\
\text { Efektif }\end{array}$ \\
\hline
\end{tabular}


Analisis Tingkat Bahaya Longsor pada Jalan Nasional untuk Prioritas Penanganan dengan Metode AHP: Studi Kasus Jalan pada Satker PJN III dan PJN IV

\begin{tabular}{|c|c|c|c|c|c|c|c|c|c|}
\hline No & Ruas & $\begin{array}{c}\text { Kemiringan } \\
\text { Tanah }\end{array}$ & $\begin{array}{c}\text { Tutupan } \\
\text { Lahan }\end{array}$ & $\begin{array}{l}\text { Curah } \\
\text { Hujan }\end{array}$ & $\begin{array}{l}\text { Tanah } \\
\text { Dasar }\end{array}$ & $\begin{array}{c}\text { Kondisi } \\
\text { Drainase }\end{array}$ & $\begin{array}{l}\text { Dimensi } \\
\text { Longsor }\end{array}$ & $\begin{array}{c}\text { Lalulintas } \\
\text { Harian }\end{array}$ & $\begin{array}{c}\text { Rekayasa } \\
\text { Lereng }\end{array}$ \\
\hline & $\begin{array}{l}\text { Bts. Kota Sibolga } \\
\text { (Sta. 020+980) }\end{array}$ & & & & & & & & \\
\hline 20 & $\begin{array}{l}\text { Bts. Kab } \\
\text { Tapanuli Utara - } \\
\text { Bts. Kota Sibolga } \\
\text { (Sta. 020+980) }\end{array}$ & $45^{\circ}$ & Semak & 3324 & $\begin{array}{l}\text { Tidak } \\
\text { Stabil }\end{array}$ & $\begin{array}{l}\text { Tidak } \\
\text { Berfungsi }\end{array}$ & $800 \mathrm{~m}^{2}$ & 1154 & $\begin{array}{l}\text { Tidak } \\
\text { Efektif }\end{array}$ \\
\hline 21 & $\begin{array}{l}\text { Bts. Kab } \\
\text { Tapanuli Utara - } \\
\text { Bts. Kota Sibolga } \\
(\text { Sta. 021+260) }\end{array}$ & $35^{\circ}$ & Semak & 3324 & $\begin{array}{l}\text { Tidak } \\
\text { Stabil }\end{array}$ & $\begin{array}{l}\text { Tidak } \\
\text { Berfungsi }\end{array}$ & $348 \mathrm{~m}^{2}$ & 1154 & $\begin{array}{l}\text { Tidak } \\
\text { Efektif }\end{array}$ \\
\hline 22 & $\begin{array}{l}\text { Bts. Kab } \\
\text { Tapanuli Utara - } \\
\text { Bts. Kota Sibolga } \\
(\text { Sta. } 021+260) \\
\end{array}$ & $43^{\circ}$ & Semak & 3324 & $\begin{array}{l}\text { Tidak } \\
\text { Stabil }\end{array}$ & $\begin{array}{l}\text { Tidak } \\
\text { Berfungsi }\end{array}$ & $285 \mathrm{~m}^{2}$ & 1154 & $\begin{array}{l}\text { Tidak } \\
\text { Efektif }\end{array}$ \\
\hline 23 & $\begin{array}{l}\text { Batang Toru - } \\
\text { Sp. Aek Rambe } \\
\text { (Sta. 017+800) }\end{array}$ & $25^{\circ}$ & Kebun & 4194 & $\begin{array}{l}\text { Tidak } \\
\text { Pasti }\end{array}$ & $\begin{array}{l}\text { Berfungsi } \\
\text { Sebagian }\end{array}$ & $224 \mathrm{~m}^{2}$ & 1154 & $\begin{array}{l}\text { Tidak } \\
\text { Efektif }\end{array}$ \\
\hline 24 & $\begin{array}{l}\text { Sp. Aek Rambe - } \\
\text { Singkuang (Sta. } \\
050+800)\end{array}$ & $40^{\circ}$ & Kebun & 4194 & $\begin{array}{l}\text { Tidak } \\
\text { Pasti }\end{array}$ & $\begin{array}{l}\text { Berfungsi } \\
\text { Sebagian }\end{array}$ & $19.5 \mathrm{~m}^{2}$ & 662 & $\begin{array}{l}\text { Tidak } \\
\text { Efektif }\end{array}$ \\
\hline 25 & $\begin{array}{lr}\text { Tetehosi } & - \\
\text { Lahusa } & \text { (Sta. } \\
033+800) & \\
\end{array}$ & $50^{\circ}$ & Kebun & 3647 & $\begin{array}{l}\text { Tidak } \\
\text { Pasti }\end{array}$ & $\begin{array}{l}\text { Berfungsi } \\
\text { Sebagian }\end{array}$ & $49.5 \mathrm{~m}^{2}$ & 662 & $\begin{array}{l}\text { Sebagian } \\
\text { Efektif }\end{array}$ \\
\hline 26 & $\begin{array}{lr}\text { Lahusa }- & \text { Teluk } \\
\text { Dalam } & \text { (Sta. } \\
017+000) & \\
\end{array}$ & $60^{\circ}$ & Kota & 3647 & $\begin{array}{l}\text { Tidak } \\
\text { Pasti }\end{array}$ & $\begin{array}{l}\text { Berfungsi } \\
\text { Sebagian }\end{array}$ & $112 \mathrm{~m}^{2}$ & 854 & $\begin{array}{l}\text { Tidak } \\
\text { Efektif }\end{array}$ \\
\hline 27 & $\begin{array}{lr}\text { Lahusa }- & \text { Teluk } \\
\text { Dalam } & \text { (Sta. } \\
021+971) & \\
\end{array}$ & $45^{\circ}$ & Kebun & 3647 & $\begin{array}{l}\text { Tidak } \\
\text { Pasti }\end{array}$ & $\begin{array}{l}\text { Tidak } \\
\text { Ada }\end{array}$ & $120 \mathrm{~m}^{2}$ & 1678 & $\begin{array}{l}\text { Sebagian } \\
\text { Efektif }\end{array}$ \\
\hline 28 & $\begin{array}{l}\text { Teluk Dalam - } \\
\text { Lolowau } \\
\text { 036+580) }\end{array}$ & $35^{\circ}$ & Kebun & 3647 & $\begin{array}{l}\text { Tidak } \\
\text { Stabil }\end{array}$ & $\begin{array}{l}\text { Berfungsi } \\
\text { Sebagian }\end{array}$ & $\begin{array}{l}112.5 \\
\mathrm{~m}^{2}\end{array}$ & 1678 & Efektif \\
\hline 29 & $\begin{array}{l}\text { Teluk Dalam - } \\
\text { Lolowau (Sta. } \\
043+180)\end{array}$ & $25^{\circ}$ & Kebun & 3647 & $\begin{array}{l}\text { Tidak } \\
\text { Stabil }\end{array}$ & $\begin{array}{l}\text { Berfungsi } \\
\text { Sebagian }\end{array}$ & $40 \mathrm{~m}^{2}$ & 1384 & $\begin{array}{l}\text { Tidak } \\
\text { Efektif }\end{array}$ \\
\hline 30 & $\begin{array}{l}\text { Teluk Dalam - } \\
\text { Lolowau } \\
046+230)\end{array}$ & $33.5^{\circ}$ & Kebun & 3647 & $\begin{array}{l}\text { Tidak } \\
\text { Stabil }\end{array}$ & $\begin{array}{l}\text { Berfungsi } \\
\text { Sebagian }\end{array}$ & $69 \mathrm{~m}^{2}$ & 1384 & $\begin{array}{l}\text { Tidak } \\
\text { Efektif }\end{array}$ \\
\hline 31 & $\begin{array}{l}\text { Teluk Dalam - } \\
\text { Lolowau } \quad \text { (Sta. } \\
049+680)\end{array}$ & $30^{\circ}$ & Kebun & 3647 & Stabil & $\begin{array}{l}\text { Berfungsi } \\
\text { Sebagian }\end{array}$ & $100 \mathrm{~m}^{2}$ & 1384 & $\begin{array}{l}\text { Tidak } \\
\text { Efektif }\end{array}$ \\
\hline 32 & $\begin{array}{l}\text { Teluk Dalam - } \\
\text { Lolowau (Sta. } \\
050+830)\end{array}$ & $30^{\circ}$ & Kebun & 3647 & $\begin{array}{l}\text { Tidak } \\
\text { Pasti }\end{array}$ & $\begin{array}{l}\text { Berfungsi } \\
\text { Sebagian }\end{array}$ & $175 \mathrm{~m}^{2}$ & 1384 & $\begin{array}{l}\text { Tidak } \\
\text { Efektif }\end{array}$ \\
\hline 33 & $\begin{array}{l}\text { Teluk Dalam - } \\
\text { Lolowau (Sta. } \\
052+780)\end{array}$ & $50^{\circ}$ & Semak & 3647 & $\begin{array}{l}\text { Tidak } \\
\text { Stabil }\end{array}$ & $\begin{array}{l}\text { Tidak } \\
\text { Ada }\end{array}$ & $140 \mathrm{~m}^{2}$ & 1384 & $\begin{array}{l}\text { Tidak } \\
\text { Efektif }\end{array}$ \\
\hline 34 & \begin{tabular}{lc} 
Teluk Dalam - & \multicolumn{1}{c}{ Dalowau } \\
Lolsta. \\
$061+810)$
\end{tabular} & $15^{\circ}$ & Kota & 3647 & $\begin{array}{l}\text { Tidak } \\
\text { Stabil }\end{array}$ & $\begin{array}{l}\text { Tidak } \\
\text { Berfungsi }\end{array}$ & $88 \mathrm{~m}^{2}$ & 1384 & Efektif \\
\hline
\end{tabular}




\section{Analisa Bobot Tingkat Bahaya Longsor}

Tingkat bahaya longsor merupakan tahapan pertama yang diperoleh dengan menggunakan metode AHP. Langkah awal adalah membuat struktur hierarki yang diawali dengan tujuan utama. Kriteria yang digunakan dalam menentukan tingkat bahaya longsor adalah kemiringan tanah (KT), tutupan lahan (TL), curah hujan (CH), tanah dasar (TD) dan kondisi drainase (KD) (Julita, 2016).

Penilaian bobot kriteria ini dilakukan dengan Focus Group Discussion dengan hasil diskusi yang dapat dilihat pada Gambar 1 berikut.

\begin{tabular}{|c|c|c|c|c|c|c|c|c|c|c|c|c|c|c|c|c|c|c|}
\hline \multirow{2}{*}{$\begin{array}{c}\text { Kriteria } \\
\text { KT }\end{array}$} & \multicolumn{17}{|c|}{ Skala Perbandingan Tingkat Kepentingan } & \multirow{2}{*}{$\begin{array}{c}\text { Kriteria } \\
\mathrm{TL}\end{array}$} \\
\hline & 9 & 8 & 7 & 6 & 5 & 4 & 3 & 2 & 1 & 2 & 3 & 4 & 5 & 6 & 7 & 8 & 9 & \\
\hline KT & 9 & 8 & 7 & 6 & 5 & 4 & 3 & 2 & 1 & 2 & 3 & 4 & 5 & 6 & 7 & 8 & 9 & $\mathrm{CH}$ \\
\hline $\mathrm{KT}$ & 9 & 8 & 7 & 6 & 5 & 4 & 3 & 2 & 1 & 2 & 3 & 4 & 5 & 6 & 7 & 8 & 9 & $\mathrm{TD}$ \\
\hline KT & 9 & 8 & 7 & 6 & 5 & 4 & 3 & 2 & 1 & 2 & 3 & 4 & 5 & 6 & 7 & 8 & 9 & KD \\
\hline $\mathrm{TL}$ & 9 & 8 & 7 & 6 & 5 & 4 & 3 & 2 & 1 & 2 & 3 & 4 & 5 & 6 & 7 & 8 & 9 & $\mathrm{CH}$ \\
\hline $\mathrm{TL}$ & 9 & 8 & 7 & 6 & 5 & 4 & 3 & 2 & 1 & 2 & 3 & 4 & 5 & 6 & 7 & 8 & 9 & TD \\
\hline TL & 9 & 8 & 7 & 6 & 5 & 4 & 3 & 2 & 1 & 2 & 3 & 4 & 5 & 6 & 7 & 8 & 9 & KD \\
\hline $\mathrm{CH}$ & 9 & 8 & 7 & 6 & 5 & 4 & 3 & 2 & 1 & 2 & 3 & 4 & 5 & 6 & 7 & 8 & 9 & TD \\
\hline $\mathrm{CH}$ & 9 & 8 & 7 & 6 & 5 & 4 & 3 & 2 & 1 & 2 & 3 & 4 & 5 & 6 & 7 & 8 & 9 & KD \\
\hline TD & 9 & 8 & 7 & 6 & 5 & 4 & 3 & 2 & 1 & 2 & 3 & 4 & 5 & 6 & 7 & 8 & 9 & KD \\
\hline
\end{tabular}

\section{Gambar 2}

\section{Penilaian Skala Perbandingan Kriteria Bahaya Longsor}

Setelah mendapatkan bobot perbandingan kepentingan masing-masing kriteria, maka selanjutnya adalah penyusunan matriks untuk perhitungan bobot kriteria. Proses ini dilakukan dengan cara membuat matrik perbandingan berpasangan yang menggambarkan kontribusi relatif atau pengaruh setiap elemen terhadap tujuan atau kriteria yang setingkat di atasnya seperti yang ditunjukan pada Tabel 1 dan gambar 2 (Lestiani, 2018).

Tabel 2

Matriks Perbandingan Kriteria Bahaya Longsor

\begin{tabular}{cccccc}
\hline & KT & TL & CH & TD & KD \\
\hline KT & $1 / 1$ & $2 / 1$ & $2 / 1$ & $3 / 1$ & $3 / 1$ \\
\hline TL & $1 / 2$ & $1 / 1$ & $1 / 2$ & $3 / 1$ & $2 / 1$ \\
\hline CH & $1 / 2$ & $2 / 1$ & $1 / 1$ & $3 / 1$ & $3 / 1$ \\
\hline TD & $1 / 3$ & $1 / 3$ & $1 / 3$ & $1 / 1$ & $3 / 1$ \\
\hline KD & $1 / 3$ & $1 / 2$ & $1 / 3$ & $1 / 3$ & $1 / 1$ \\
\hline
\end{tabular}

Dengan menyusun matriks maka dapat didefinisikan perbandingan berpasangan terhadap masing-masing kriteria. Langkah selanjutnya adalah menghitung nilai eigen masing-masing kriteria dengan cara normalisasi matriks. Setelah mendapatkan matriks normalisasi kriteria maka didapatkan nilai eigen 
Analisis Tingkat Bahaya Longsor pada Jalan Nasional untuk Prioritas Penanganan dengan Metode AHP: Studi Kasus Jalan pada Satker PJN III dan PJN IV

masing-masing kriteria dengan cara mencari rata-rata untuk setiap baris kriteria. Hasil matriks dapat dilihat pada Tabel 2 (Setiawan, Ananto, \& Soehartanto, 2020).

Tabel 3

Sintesis Matriks Kriteria Bahaya Longsor

\begin{tabular}{ccccccc}
\hline & KT & TL & CH & TD & KD & $\sum$ Xi \\
\hline KT & 0,38 & 0,34 & 0,48 & 0,29 & 0,25 & $\mathbf{0 , 3 5}$ \\
\hline TL & 0,19 & 0,17 & 0,12 & 0,29 & 0,17 & $\mathbf{0 , 1 9}$ \\
\hline CH & 0,19 & 0,34 & 0,24 & 0,29 & 0,25 & $\mathbf{0 , 2 6}$ \\
\hline TD & 0,13 & 0,06 & 0,08 & 0,10 & 0,25 & $\mathbf{0 , 1 2}$ \\
\hline KD & 0,13 & 0,09 & 0,08 & 0,03 & 0,08 & $\mathbf{0 , 0 8}$ \\
\hline Jumlah & $\mathbf{1 , 0 0}$ & $\mathbf{1 , 0 0}$ & $\mathbf{1 , 0 0}$ & $\mathbf{1 , 0 0}$ & $\mathbf{1 , 0 0}$ & \\
\hline
\end{tabular}

Setelah melakukan normalisasi dan mendapatkan nilai eigen masing-masing kriteria, langkah selanjutnya adalah menghitung konsistensi hierarki yang telah dibuat dengan ketentuan $\mathrm{CR}<0.1$. Matriks yang telah dinormalisasi akan dikalikan dengan nilai eigen masing-masing kriteria sebagai berikut:

$$
\left\{\begin{array}{lllll}
0,38 & 0,34 & 0,48 & 0,29 & 0,25 \\
0,19 & 0,17 & 0,12 & 0,29 & 0,17 \\
0,19 & 0,34 & 0,24 & 0,29 & 0,25 \\
0,13 & 0,06 & 0,08 & 0,10 & 0,25 \\
0,13 & 0,09 & 0,08 & 0,03 & 0,08
\end{array}\right\} \times\left\{\begin{array}{l}
0,35 \\
0,19 \\
0,26 \\
0,12 \\
0,08
\end{array}\right\} \begin{array}{r}
\mathbf{1 , 8 6} \\
\mathbf{1 , 0 2} \\
\mathbf{1 , 4 2} \\
\mathbf{0 , 6 3} \\
\mathbf{0 , 4 2}
\end{array}
$$

Hasil perkalian matriks di atas lalu dibagi dengan nilai eigen masing-masing kriteria dengan menggunakan Persamaan (2-3), sehingga menghasilkan perhitungan sebagai berikut:

$$
\begin{aligned}
& \frac{1,86}{0,35}=5,34 \\
& \frac{1,02}{0,19}=5,45 \\
& \frac{1,42}{0,26}=5,41 \\
& \frac{0,63}{0,12}=5,18 \\
& \frac{0,42}{0,08}=5,15
\end{aligned}
$$

Dari perhitungan diatas, dengan menggunakan Persamaan (2-4) maka didapat nilai $\lambda$ maksimum yaitu:

$$
\lambda_{\text {maks }}=\frac{(5,34+5,45+5,41+5,18+5,15)}{5}=\mathbf{5 , 3 1}
$$

Langkah selanjutnya adalah menghitung concistency index (CI) dengan menggunakan Persamaan (2-5) sehingga menghasilkan perhitungan sebagai berikut: 


$$
\begin{aligned}
C I & =\frac{(5,31-5)}{(5-1)} \\
& =\mathbf{0 , 0 8}
\end{aligned}
$$

Setelah mendapatkan nilai consistency index (CI) maka dapat dihitung nilai concistency ratio $(\mathrm{CR})<0,1$ dengan Persamaan (2-6). Berdasarkan pada Tabel 2.5 dapat diketahui untuk $n=5$, maka nilai random index $(R I)=1,12$.

$$
\begin{aligned}
\mathrm{CR} & =\frac{0,08}{1,12} \\
& =\mathbf{0 , 0 7}<\mathbf{0 , 1}
\end{aligned}
$$

Dari hasil nilai $\mathrm{CR}=0,07<0.1$, maka perhitungan AHP dalam mengambil keputusan telah memenuhi syarat. Hasil perhitungan bobot utama dapat dilihat pada Tabel 4

\section{Tabel 4}

Hasil Perhitungan AHP Kriteria Bahaya Longsor

\begin{tabular}{cc}
\hline Kriteria & Bobot \\
\hline Kemiringan Tanah & $\mathbf{0 , 3 5}$ \\
\hline Tutupan Lahan & $\mathbf{0 , 1 9}$ \\
\hline Curah Hujan & $\mathbf{0 , 2 6}$ \\
\hline Tanah Dasar & $\mathbf{0 , 1 2}$ \\
\hline Kondisi Drainase & $\mathbf{0 , 0 8}$ \\
\hline
\end{tabular}

\section{Analisa Bobot Kriteria Bahaya Longsor}

Sementara untuk tingkat prioritas penanganan jalan menggunakan tingkat bahaya longsor (BL) sebagai parameter dikombinasikan dengan tiga parameter lainnya yaitu dimensi longsor (DL), rekayasa lereng yang ada (RL) dan lalulintas

\begin{tabular}{|c|c|c|c|c|c|c|c|c|c|c|c|c|c|c|c|c|c|c|}
\hline \multirow{3}{*}{$\begin{array}{c}\text { Kriteria } \\
\text { BL }\end{array}$} & \multicolumn{17}{|c|}{ Skala Perbandingan Tingkat Kepentingan } & Kriteria \\
\hline & & & & & & & & & & & & & & & & & & \\
\hline & 9 & 8 & 7 & 6 & 5 & 4 & 3 & 2 & 1 & 2 & 3 & 4 & 5 & 6 & 7 & 8 & 9 & DL \\
\hline BL & 9 & 8 & 7 & 6 & 5 & 4 & 3 & 2 & 1 & 2 & 3 & 4 & 5 & 6 & 7 & 8 & 9 & RL \\
\hline BL & 9 & 8 & 7 & 6 & 5 & 4 & 3 & 2 & 1 & 2 & 3 & 4 & 5 & 6 & 7 & 8 & 9 & LH \\
\hline DL & 9 & 8 & 7 & 6 & 5 & 4 & 3 & 2 & 1 & 2 & 3 & 4 & 5 & 6 & 7 & 8 & 9 & RL \\
\hline DL & 9 & 8 & 7 & 6 & 5 & 4 & 3 & 2 & 1 & 2 & 3 & 4 & 5 & 6 & 7 & 8 & 9 & $\mathrm{LH}$ \\
\hline $\mathrm{RL}$ & 9 & 8 & 7 & 6 & 5 & 4 & 3 & 2 & 1 & 2 & 3 & 4 & 5 & 6 & 7 & 8 & 9 & LH \\
\hline
\end{tabular}
harian rata-rata $(\mathrm{LH})$.

Penilaian bobot kriteria ini dilakukan dengan Focus Group Discussion. Hasil diskusi ini dapat dilihat pada Gambar 3 berikut.

\section{Gambar 3}

Penilaian Skala Perbandingan Kriteria Prioritas Penanganan Jalan 
Setelah mendapatkan bobot perbandingan kepentingan masing-masing kriteria, maka selanjutnya adalah penyusunan matriks untuk perhitungan bobot kriteria. Proses ini dilakukan dengan cara membuat matrik perbandingan berpasangan yang menggambarkan kontribusi relatif atau pengaruh setiap elemen terhadap tujuan atau kriteria yang setingkat di atasnya seperti yang ditunjukan pada Tabel 5 dan 6 (Mujiastuti, Meilina, \& Pramudiaji, 2017).

\section{Tabel 5}

Matriks Perbandingan Kriteria Prioritas Penanganan Jalan

\begin{tabular}{lllll}
\hline & BL & DL & RL & LH \\
\hline BL & $1 / 1$ & $1 / 1$ & $3 / 1$ & $2 / 1$ \\
\hline $\mathbf{D L}$ & $1 / 1$ & $1 / 1$ & $2 / 1$ & $2 / 1$ \\
\hline $\mathbf{R L}$ & $1 / 3$ & $1 / 2$ & $1 / 1$ & $1 / 1$ \\
\hline $\mathbf{L H}$ & $1 / 2$ & $1 / 2$ & $1 / 1$ & $1 / 1$ \\
\hline
\end{tabular}

\section{Tabel 6}

Matriks Perbandingan Kriteria Prioritas Penanganan Jalan

\begin{tabular}{ccccc}
\hline & $\mathbf{B L}$ & $\mathbf{D L}$ & $\mathbf{R L}$ & $\mathbf{L H}$ \\
\hline BL & 1,000 & 1,000 & 3,000 & 2,000 \\
\hline DL & 1,000 & 1,000 & 2,000 & 2,000 \\
\hline RL & 0,333 & 0,500 & 1,000 & 1,000 \\
\hline LH & 0,500 & 0,500 & 1,000 & 1,000 \\
\hline Jumlah & $\mathbf{2 , 8 3 3}$ & $\mathbf{3 , 0 0 0}$ & $\mathbf{7 , 0 0 0}$ & $\mathbf{6 , 0 0 0}$ \\
\hline
\end{tabular}

Dengan menyusun matriks maka dapat didefinisikan perbandingan berpasangan terhadap masing-masing kriteria. Langkah selanjutnya adalah menghitung nilai eigen masing-masing kriteria dengan cara normalisasi matriks dengan proses perhitungan menggunakan Persamaan (2-1) sebagai berikut (Rianto, 2016):

\section{Kolom 1:}

$$
\begin{aligned}
& \frac{1,000}{2,283}=0,353 \\
& \frac{1,000}{2,283}=0,353 \\
& \frac{0,333}{2,283}=0,118 \\
& \frac{0,500}{2,283}=0,176
\end{aligned}
$$

Langkah ini dilakukan untuk setiap kolom. Setelah mendapatkan matriks normalisasi kriteria maka didapatkan nilai eigen masing-masing kriteria dengan cara mencari rata-rata untuk setiap baris kriteria. Hasil matriks dapat dilihat pada Tabel 13. 
Tabel 7

Sintesis Matriks Kriteria Prioritas Penanganan Jalan

\begin{tabular}{cccccc}
\hline & BL & DL & RL & LH & $\sum$ Xi \\
\hline BL & 0,353 & 0,333 & 0,429 & 0,333 & $\mathbf{0 , 3 6 2}$ \\
\hline DL & 0,353 & 0,333 & 0,286 & 0,333 & $\mathbf{0 , 3 2 6}$ \\
\hline RL & 0,118 & 0,167 & 0,143 & 0,167 & $\mathbf{0 , 1 4 8}$ \\
\hline LH & 0,176 & 0,167 & 0,143 & 0,167 & $\mathbf{0 , 1 6 3}$ \\
\hline Jumlah & $\mathbf{1 , 0 0 0}$ & $\mathbf{1 , 0 0 0}$ & $\mathbf{1 , 0 0 0}$ & $\mathbf{1 , 0 0 0}$ & \\
\hline
\end{tabular}

Setelah melakukan normalisasi dan mencari nilai eigen masing-masing kriteria, langkah selanjutnya adalah menghitung konsistensi hierarki yang telah dibuat dengan ketentuan $\mathrm{CR}<0.1$. Matriks yang telah dinormalisasi akan dikalikan dengan nilai eigen masing-masing kriteria sebagai berikut:

$$
\left\{\begin{array}{llll}
0,353 & 0,333 & 0,429 & 0,333 \\
0,353 & 0,333 & 0,286 & 0,333 \\
0,118 & 0,167 & 0,143 & 0,167 \\
0,176 & 0,167 & 0,143 & 0,167
\end{array}\right\} \times\left\{\begin{array}{l}
0,362 \\
0,326 \\
0148 \\
0,163
\end{array}\right\} \begin{array}{r}
\mathbf{1 , 4 6 0} \\
\mathbf{1}, \mathbf{3 1 2} \\
\mathbf{0 , 5 9 5} \\
\mathbf{0 , 6 5 6}
\end{array}
$$

Hasil perkalian matriks di atas lalu dibagi dengan nilai eigen masing-masing kriteria, sehingga menghasilkan perhitungan dengan menggunakan Persamaan (2-3) sebagai berikut:

$$
\begin{aligned}
& \frac{1,460}{1,312}=4,033 \\
& \frac{1,312}{0,326}=4,019 \\
& \frac{0,595}{0,148}=4,011 \\
& \frac{0,656}{0,163}=4,019
\end{aligned}
$$

Dari perhitungan diatas maka didapat nilai $\lambda$ maksimum dengan Persamaan (24) yaitu:

$$
\lambda_{\text {maks }}=\frac{(4,033+4,019+4,011+4,019)}{4}=\mathbf{4 , 0 2 1}
$$

Langkah selanjutnya adalah menghitung concistency index (CI) dengan menggunakan Persamaan (2-5), sehingga menghasilkan perhitungan sebagai berikut:

$$
\begin{aligned}
C I & =\frac{(4,021-4)}{(4-1)} \\
& =\mathbf{0 , 0 0 7}
\end{aligned}
$$


Setelah mendapatkan nilai consistency index (CI) maka dapat dihitung nilai concistency ratio $(\mathrm{CR})<0,1$ dengan Persamaan (2-6). Berdasarkan pada Tabel 2.5 dapat diketahui untuk $n=4$, maka nilai random index $(R I)=0,90$.

$$
\begin{aligned}
C R & =\frac{0,007}{0,90} \\
& =\mathbf{0 , 0 0 8}<\mathbf{0 , 1}
\end{aligned}
$$

Dari hasil nilai $\mathrm{CR}=0.008<0.1$, maka perhitungan AHP dalam mengambil keputusan telah memenuhi syarat. Hasil perhitungan bobot utama dapat dilihat pada Tabel 8.

Tabel 8

Hasil Perhitungan AHP Kriteria Prioritas Penanganan Jalan

\begin{tabular}{cc}
\hline Kriteria & Bobot \\
\hline Bahaya Longsor & $\mathbf{0 , 3 6 2}$ \\
\hline Dimensi Longsor & $\mathbf{0 , 3 2 6}$ \\
\hline Rekayasa Lereng & $\mathbf{0 , 1 4 8}$ \\
\hline Lalulintas Harian & $\mathbf{0 , 1 6 3}$ \\
\hline
\end{tabular}

3. Analisa Tingkat Bahaya Longsor

Nilai indeks masing-masing kriteria yaitu kemiringan tanah, tutupan lahan, curah hujan, tanah dasar, kondisi drainase, diperoleh dari Puslittanak 2004, Permen PU No.19/PRT/M/2011 dan Draft Pedoman Penilaian Tingkat Resiko Lereng Jalan yang dikeluarkan Kementrian Pekerjaan Umum dan Perumahan Rakyat pada tahun 2018. Nilai Indeks masing-masing kriteria tersebut dapat dilihat pada Tabel 9.

Tabel 9

Nilai Indeks Kriteria

\begin{tabular}{lllccccc}
\hline \multicolumn{1}{c}{ Ruas } & & $\begin{array}{c}\text { Kemiringan } \\
\text { Tanah }\end{array}$ & $\begin{array}{c}\text { Tutupan } \\
\text { Lahan }\end{array}$ & $\begin{array}{c}\text { Curah } \\
\text { Hujan }\end{array}$ & $\begin{array}{c}\text { Tanah } \\
\text { Dasar }\end{array}$ & $\begin{array}{c}\text { Kondisi } \\
\text { Drainase }\end{array}$ \\
\hline 1 & $\begin{array}{l}\text { Bts. Kota Medan }- \text { Bts. Kab. Karo } \\
\text { (Sta 010+250) }\end{array}$ & 5 & 3 & 2 & 8 & 3 \\
\hline 2 & $\begin{array}{l}\text { Bts. Kota Medan - Bts. Kab. Karo } \\
\text { (Sta 021+950) }\end{array}$ & 5 & 3 & 2 & 0 & 3 \\
\hline 3 & $\begin{array}{l}\text { Merek - Bts. Kab. Dairi (Sta } \\
\text { 099+100) }\end{array}$ & 5 & 3 & 2 & 8 & 3 \\
\hline 4 & $\begin{array}{l}\text { Merek - Bts. Kab. Dairi (Sta } \\
\text { 099+100) }\end{array}$ & 5 & 3 & 2 & 8 & 3 \\
\hline 5 & $\begin{array}{l}\text { Tiga Rungu - Tanjung Dolok (Sta } \\
\text { 125+310) }\end{array}$ & 5 & 3 & 5 & 8 & 2 \\
\hline 6 & $\begin{array}{l}\text { Jln. Kutacane - Bts. Kota } \\
\text { Kabanjahe - Kuta Buluh (Sta. } \\
\text { 049+550) }\end{array}$ & 5 & 3 & 2 & 3 & 1 \\
\hline 7 & $\begin{array}{l}\text { Jln. Kutacane - Bts. Kota } \\
\text { Kabanjahe - Kuta Buluh (Sta. } \\
\text { 050+450) }\end{array}$ & 5 & 3 & 2 & 8 & 3 \\
\hline
\end{tabular}




\begin{tabular}{|c|c|c|c|c|c|c|}
\hline No & Ruas & $\begin{array}{l}\text { Kemiringan } \\
\text { Tanah }\end{array}$ & $\begin{array}{l}\text { Tutupan } \\
\text { Lahan }\end{array}$ & $\begin{array}{l}\text { Curah } \\
\text { Hujan }\end{array}$ & $\begin{array}{l}\text { Tanah } \\
\text { Dasar }\end{array}$ & $\begin{array}{l}\text { Kondisi } \\
\text { Drainase }\end{array}$ \\
\hline 8 & $\begin{array}{llcl}\text { Jln. Kutacane }- & \text { Bts. } & \text { Kota } \\
\text { Kabanjahe }- \text { Kuta } & \text { Buluh } & \text { (Sta. } \\
\text { 050+450) } & & & \\
\end{array}$ & 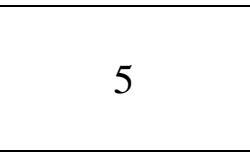 & 3 & 2 & 8 & 3 \\
\hline 9 & $\begin{array}{l}\text { Kuta Buluh - Bts. Kota Sidikalang } \\
\text { (Sta. 018+040) }\end{array}$ & 5 & 4 & 2 & 8 & 4 \\
\hline 10 & $\begin{array}{l}\text { Kuta Buluh - Bts. Kota Sidikalang } \\
(\text { Sta. 028+375) }\end{array}$ & 5 & 4 & 2 & 8 & 4 \\
\hline 11 & $\begin{array}{l}\text { Kuta Buluh - Bts. Kota Sidikalang } \\
\text { (Sta. 033+110) }\end{array}$ & 5 & 3 & 2 & 3 & 1 \\
\hline 12 & $\begin{array}{l}\text { Barus - Bts. Kota Sibolga (Sta. } \\
010+515)\end{array}$ & 4 & 3 & 3 & 8 & 2 \\
\hline 13 & $\begin{array}{l}\text { Rampa - Poriaha/Mungkur (Sta. } \\
007+000)\end{array}$ & 5 & 3 & 5 & 8 & 3 \\
\hline 14 & $\begin{array}{l}\text { Rampa - Poriaha/Mungkur (Sta. } \\
007+000)\end{array}$ & 5 & 3 & 5 & 8 & 3 \\
\hline 15 & $\begin{array}{l}\text { Bts. Kota Tarutung - Bts. Kab. } \\
\text { Tapanuli Tengah (Sta. } 023+580)\end{array}$ & 5 & 4 & 4 & 8 & 3 \\
\hline 16 & $\begin{array}{l}\text { Bts. Kota Tarutung - Bts. Kab. } \\
\text { Tapanuli Tengah (Sta. } 030+400)\end{array}$ & 4 & 3 & 4 & 8 & 1 \\
\hline 17 & $\begin{array}{l}\text { Bts. Kota Tarutung - Bts. Kab. } \\
\text { Tapanuli Tengah (Sta. } 032+680)\end{array}$ & 5 & 4 & 4 & 8 & 3 \\
\hline 18 & $\begin{array}{l}\text { Bts. Kota Tarutung - Bts. Kab. } \\
\text { Tapanuli Tengah (Sta. } 045+100)\end{array}$ & 5 & 3 & 4 & 3 & 1 \\
\hline 19 & $\begin{array}{l}\text { Bts. Kab Tapanuli Utara - Bts. Kota } \\
\text { Sibolga (Sta. } 020+980)\end{array}$ & 5 & 4 & 5 & 8 & 3 \\
\hline 20 & $\begin{array}{l}\text { Bts. Kab Tapanuli Utara - Bts. Kota } \\
\text { Sibolga (Sta. 020+980) }\end{array}$ & 5 & 4 & 5 & 8 & 3 \\
\hline 21 & $\begin{array}{l}\text { Bts. Kab Tapanuli Utara - Bts. Kota } \\
\text { Sibolga (Sta. 021+260) }\end{array}$ & 5 & 4 & 5 & 8 & 3 \\
\hline 22 & $\begin{array}{l}\text { Bts. Kab Tapanuli Utara - Bts. Kota } \\
\text { Sibolga (Sta. 021+260) }\end{array}$ & 5 & 4 & 5 & 8 & 3 \\
\hline 23 & $\begin{array}{l}\text { Batang Toru - Sp. Aek Rambe (Sta. } \\
017+800)\end{array}$ & 5 & 3 & 5 & 3 & 2 \\
\hline 24 & $\begin{array}{l}\text { Sp. Aek Rambe - Singkuang (Sta. } \\
050+800)\end{array}$ & 5 & 3 & 5 & 3 & 2 \\
\hline 25 & Tetehosi - Lahusa (Sta. 033+800) & 5 & 3 & 5 & 3 & 2 \\
\hline 26 & $\begin{array}{l}\text { Lahusa }- \text { Teluk Dalam } \quad \text { (Sta. } \\
017+000)\end{array}$ & 5 & 2 & 5 & 3 & 2 \\
\hline 27 & $\begin{array}{l}\text { Lahusa }- \text { Teluk Dalam } \quad \text { (Sta. } \\
021+971)\end{array}$ & 5 & 3 & 5 & 3 & 4 \\
\hline 28 & $\begin{array}{l}\text { Teluk Dalam }- \text { Lolowau (Sta. } \\
036+580)\end{array}$ & 5 & 3 & 5 & 8 & 2 \\
\hline 29 & $\begin{array}{l}\text { Teluk Dalam - Lolowau (Sta. } \\
043+180)\end{array}$ & 5 & 3 & 5 & 8 & 2 \\
\hline
\end{tabular}




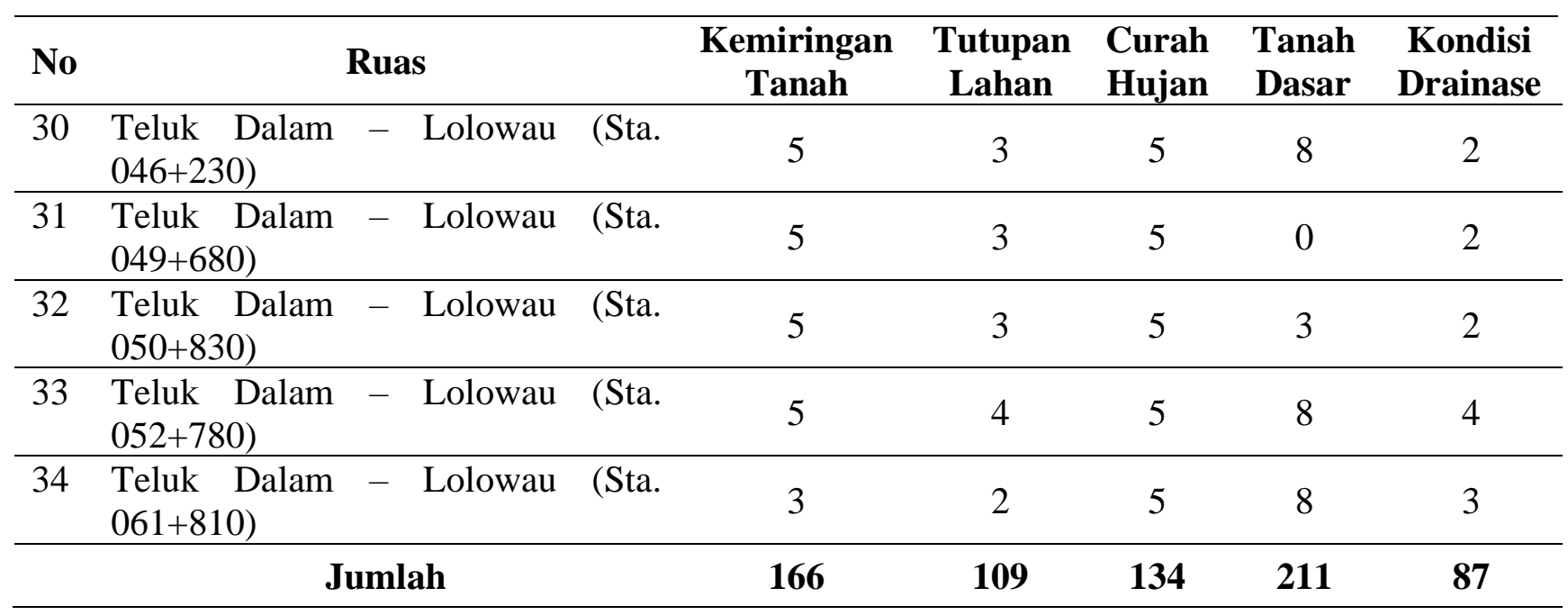

Dalam melakukan perangkingan tingkat bahaya longsor untuk masing-masing titik longsor yang terjadi pada setiap ruas jalan, maka dilakukan perhitungan perkalian nilai eigen alternatif dengan nilai bobot kriteria pada setiap kriteria yang bersesuaian. Nilai eigen alternatif diperoleh dengan melakukan normalisasi pada setiap nilai kriteria pada alternatif dengan kriteria yang bersesuaian. Untuk mendapatkan perangkingan tingkat bahaya longsor yang terjadi pada masing-masing ruas jalan Nasional di Provinsi Sumatera Utara khususnya pada area Satker PJN III dan PJN IV dilakukan perkalian nilai eigen alternatif dengan bobot kriteria. Hasil perangkingan tingkat bahaya longsor dapat dilihat pada Tabel 10.

Tabel 10

Hasil Perhitungan Tingkat Bahaya Longsor

\begin{tabular}{|c|c|c|c|c|c|c|c|}
\hline No. & Ruas & $\begin{array}{l}\text { KT } \\
(\mathbf{0 . 3 5})\end{array}$ & $\begin{array}{c}\text { TL } \\
(0.19)\end{array}$ & $\begin{array}{c}\text { CH } \\
(0.26)\end{array}$ & $\begin{array}{c}\text { TD } \\
(\mathbf{0 . 1 2})\end{array}$ & $\begin{array}{l}\text { KD } \\
(\mathbf{0 . 0 8})\end{array}$ & Hasil \\
\hline 1 & $\begin{array}{l}\text { Bts. Kota Medan - Bts. Kab. Karo } \\
(\text { Sta 010+250) }\end{array}$ & 0,010 & 0,005 & 0,004 & 0,005 & 0,003 & 0,027 \\
\hline 2 & $\begin{array}{l}\text { Bts. Kota Medan - Bts. Kab. Karo } \\
\text { (Sta 021+950) }\end{array}$ & 0,010 & 0,005 & 0,004 & 0,000 & 0,003 & 0,022 \\
\hline 3 & $\begin{array}{l}\text { Merek - Bts. Kab. Dairi (Sta } \\
099+100)\end{array}$ & 0,010 & 0,005 & 0,004 & 0,005 & 0,003 & 0,027 \\
\hline 4 & $\begin{array}{l}\text { Merek - Bts. Kab. Dairi (Sta } \\
099+100)\end{array}$ & 0,010 & 0,005 & 0,004 & 0,005 & 0,003 & 0,027 \\
\hline 5 & $\begin{array}{l}\text { Tiga Rungu - Tanjung Dolok (Sta } \\
125+310)\end{array}$ & 0,010 & 0,005 & 0,010 & 0,005 & 0,002 & 0,032 \\
\hline 6 & $\begin{array}{lll}\text { Jln. Kutacane }- & \text { Bts. } & \text { Kota } \\
\text { Kabanjahe }- \text { Kuta } & \text { Buluh } & \text { (Sta. } \\
049+550) & & \end{array}$ & 0,010 & 0,005 & 0,004 & 0,002 & 0,001 & 0,022 \\
\hline 7 & $\begin{array}{llll}\text { Jln. Kutacane }- & \text { Bts. } & \text { Kota } \\
\text { Kabanjahe }- \text { Kuta } & \text { Buluh } & \text { (Sta. } \\
050+450) & & & \end{array}$ & 0,010 & 0,005 & 0,004 & 0,005 & 0,003 & 0,027 \\
\hline 8 & Jln. Kutacane & 0,010 & 0,005 & 0,004 & 0,005 & 0,003 & 0,027 \\
\hline
\end{tabular}




\begin{tabular}{|c|c|c|c|c|c|c|c|}
\hline No. & Ruas & $\begin{array}{c}\text { KT } \\
(\mathbf{0 . 3 5})\end{array}$ & $\begin{array}{l}\text { TL } \\
(0.19)\end{array}$ & $\begin{array}{l}\text { CH } \\
(0.26)\end{array}$ & $\begin{array}{c}\text { TD } \\
(0.12)\end{array}$ & $\begin{array}{l}\text { KD } \\
(\mathbf{0 . 0 8})\end{array}$ & Hasil \\
\hline & $\begin{array}{l}\text { Kabanjahe - Kuta Buluh (Sta. } \\
050+450)\end{array}$ & & & & & & \\
\hline 9 & $\begin{array}{l}\text { Kuta Buluh - Bts. Kota Sidikalang } \\
\text { (Sta. 018+040) }\end{array}$ & 0,010 & 0,007 & 0,004 & 0,005 & 0,004 & 0,030 \\
\hline 10 & $\begin{array}{l}\text { Kuta Buluh - Bts. Kota Sidikalang } \\
\text { (Sta. 028+375) }\end{array}$ & 0,010 & 0,007 & 0,004 & 0,005 & 0,004 & 0,030 \\
\hline 11 & $\begin{array}{l}\text { Kuta Buluh - Bts. Kota Sidikalang } \\
\text { (Sta. 033+110) }\end{array}$ & 0,010 & 0,005 & 0,004 & 0,002 & 0,001 & 0,022 \\
\hline 12 & $\begin{array}{l}\text { Barus - Bts. Kota Sibolga (Sta. } \\
010+515)\end{array}$ & 0,008 & 0,005 & 0,006 & 0,005 & 0,002 & $\mathbf{0 , 0 2 6}$ \\
\hline 13 & $\begin{array}{l}\text { Rampa - Poriaha/Mungkur (Sta. } \\
007+000)\end{array}$ & 0,010 & 0,005 & 0,010 & 0,005 & 0,003 & 0,033 \\
\hline 14 & $\begin{array}{l}\text { Rampa - Poriaha/Mungkur (Sta. } \\
007+000)\end{array}$ & 0,010 & 0,005 & 0,010 & 0,005 & 0,003 & $\mathbf{0 , 0 3 3}$ \\
\hline 15 & $\begin{array}{l}\text { Bts. Kota Tarutung - Bts. Kab. } \\
\text { Tapanuli Tengah (Sta. } 023+580)\end{array}$ & 0,010 & 0,007 & 0,008 & 0,005 & 0,003 & 0,033 \\
\hline 16 & $\begin{array}{l}\text { Bts. Kota Tarutung - Bts. Kab. } \\
\text { Tapanuli Tengah (Sta. 030+400) }\end{array}$ & 0,008 & 0,005 & 0,008 & 0,005 & 0,001 & 0,027 \\
\hline 17 & $\begin{array}{l}\text { Bts. Kota Tarutung - Bts. Kab. } \\
\text { Tapanuli Tengah (Sta. 032+680) }\end{array}$ & 0,010 & 0,007 & 0,008 & 0,005 & 0,003 & 0,033 \\
\hline 18 & $\begin{array}{l}\text { Bts. Kota Tarutung - Bts. Kab. } \\
\text { Tapanuli Tengah (Sta. } 045+100 \text { ) }\end{array}$ & 0,010 & 0,005 & 0,008 & 0,002 & 0,001 & 0,026 \\
\hline 19 & $\begin{array}{l}\text { Bts. Kab Tapanuli Utara - Bts. } \\
\text { Kota Sibolga (Sta. } 020+980 \text { ) }\end{array}$ & 0,010 & 0,007 & 0,010 & 0,005 & 0,003 & 0,035 \\
\hline 20 & $\begin{array}{l}\text { Bts. Kab Tapanuli Utara - Bts. } \\
\text { Kota Sibolga (Sta. } 020+980 \text { ) }\end{array}$ & 0,010 & 0,007 & 0,010 & 0,005 & 0,003 & 0,035 \\
\hline 21 & $\begin{array}{l}\text { Bts. Kab Tapanuli Utara - Bts. } \\
\text { Kota Sibolga (Sta. } 021+260)\end{array}$ & 0,010 & 0,007 & 0,010 & 0,005 & 0,003 & 0,035 \\
\hline 22 & $\begin{array}{l}\text { Bts. Kab Tapanuli Utara - Bts. } \\
\text { Kota Sibolga (Sta. } 021+260 \text { ) }\end{array}$ & 0,010 & 0,007 & 0,010 & 0,005 & 0,003 & 0,035 \\
\hline 23 & $\begin{array}{l}\text { Batang Toru - Sp. Aek Rambe (Sta. } \\
017+800)\end{array}$ & 0,010 & 0,005 & 0,010 & 0,002 & 0,002 & 0,029 \\
\hline 24 & $\begin{array}{l}\text { Sp. Aek Rambe - Singkuang (Sta. } \\
050+800)\end{array}$ & 0,010 & 0,005 & 0,010 & 0,002 & 0,002 & 0,029 \\
\hline 25 & Tetehosi - Lahusa (Sta. 033+800) & 0,010 & 0,005 & 0,010 & 0,002 & 0,002 & $\mathbf{0 , 0 2 9}$ \\
\hline 26 & $\begin{array}{l}\text { Lahusa }- \text { Teluk Dalam } \\
017+000)\end{array}$ & 0,010 & 0,003 & 0,010 & 0,002 & 0,002 & 0,027 \\
\hline 27 & $\begin{array}{l}\text { Lahusa - Teluk Dalam } \\
\text { 021+971) }\end{array}$ & 0,010 & 0,005 & 0,010 & 0,002 & 0,004 & 0,031 \\
\hline 28 & $\begin{array}{l}\text { Teluk Dalam - Lolowau (Sta. } \\
036+580)\end{array}$ & 0,010 & 0,005 & 0,010 & 0,005 & 0,002 & 0,032 \\
\hline 29 & $\begin{array}{l}\text { Teluk Dalam - Lolowau (Sta. } \\
043+180)\end{array}$ & 0,010 & 0,005 & 0,010 & 0,005 & 0,002 & 0,032 \\
\hline 30 & $\begin{array}{l}\text { Teluk Dalam - Lolowau (Sta. } \\
046+230)\end{array}$ & 0,010 & 0,005 & 0,010 & 0,005 & 0,002 & $\mathbf{0 , 0 3 2}$ \\
\hline
\end{tabular}


Analisis Tingkat Bahaya Longsor pada Jalan Nasional untuk Prioritas Penanganan dengan Metode AHP: Studi Kasus Jalan pada Satker PJN III dan PJN IV

\begin{tabular}{|c|c|c|c|c|c|c|c|c|c|}
\hline No. & & Ruas & & $\begin{array}{c}\text { KT } \\
(\mathbf{0 . 3 5}) \\
\end{array}$ & $\begin{array}{c}\text { TL } \\
(\mathbf{0 . 1 9})\end{array}$ & $\begin{array}{c}\text { CH } \\
(0.26) \\
\end{array}$ & $\begin{array}{c}\text { TD } \\
(0.12) \\
\end{array}$ & $\begin{array}{c}\text { KD } \\
(\mathbf{0 . 0 8}) \\
\end{array}$ & Hasil \\
\hline 31 & $\begin{array}{l}\text { Teluk Dalam } \\
049+680)\end{array}$ & - Lolowau & & 0,010 & 0,005 & 0,010 & 0,000 & 0,002 & $\mathbf{0 , 0 2 7}$ \\
\hline 32 & $\begin{array}{l}\text { Teluk Dalam } \\
050+830)\end{array}$ & - Lolowau & (Sta. & 0,010 & 0,005 & 0,010 & 0,002 & 0,002 & \\
\hline 33 & $\begin{array}{l}\text { Teluk Dalam } \\
052+780)\end{array}$ & - Lolowau & (Sta. & 0,010 & 0,007 & 0,010 & 0,005 & 0,004 & $\mathbf{0 , 0 3 5}$ \\
\hline 34 & $\begin{array}{l}\text { Teluk Dalam } \\
061+810)\end{array}$ & - Lolowau & (Sta. & 0,006 & 0,003 & 0,010 & 0,005 & 0,003 & $\mathbf{0 , 0 2 7}$ \\
\hline
\end{tabular}

Dari hasil perhitungan tingkat bahaya longsor maka dapat dilakukan perangkingan seperti pada Tabel 11 yang akan menjelaskan hasil rekapitulasi tingkat bahaya longsor pada masing-masing ruas jalan.

\section{Tabel 11}

Rekapitulasi Tingkat Bahaya Longsor

\section{Ruas}

\begin{tabular}{lcc}
\hline & Longsor & \\
\hline Bts. Kab Tapanuli Utara - Bts. Kota Sibolga (Sta. 020+980) & $\mathbf{0 , 0 3 5}$ & $\mathbf{1}$ \\
\hline Bts. Kab Tapanuli Utara - Bts. Kota Sibolga (Sta. 020+980) & $\mathbf{0 , 0 3 5}$ & $\mathbf{1}$ \\
\hline Bts. Kab Tapanuli Utara - Bts. Kota Sibolga (Sta. 021+260) & $\mathbf{0 , 0 3 5}$ & $\mathbf{1}$ \\
\hline Bts. Kab Tapanuli Utara - Bts. Kota Sibolga (Sta. 021+260) & $\mathbf{0 , 0 3 5}$ & $\mathbf{1}$ \\
\hline Teluk Dalam - Lolowau (Sta. 052+780) & $\mathbf{0 , 0 3 5}$ & $\mathbf{1}$ \\
\hline Rampa - Poriaha/Mungkur (Sta. 007+000) & $\mathbf{0 , 0 3 3}$ & $\mathbf{6}$ \\
\hline Rampa - Poriaha/Mungkur (Sta. 007+000) & $\mathbf{0 , 0 3 3}$ & $\mathbf{6}$ \\
\hline Bts. Kota Tarutung - Bts. Kab. Tapanuli Tengah (Sta. 023+580) & $\mathbf{0 , 0 3 3}$ & $\mathbf{6}$ \\
\hline Bts. Kota Tarutung - Bts. Kab. Tapanuli Tengah (Sta. 032+680) & $\mathbf{0 , 0 3 3}$ & $\mathbf{6}$ \\
\hline Tiga Rungu - Tanjung Dolok (Sta 125+310) & $\mathbf{0 , 0 3 2}$ & $\mathbf{1 0}$ \\
\hline Teluk Dalam - Lolowau (Sta. 036+580) & $\mathbf{0 , 0 3 2}$ & $\mathbf{1 0}$ \\
\hline Teluk Dalam - Lolowau (Sta. 043+180) & $\mathbf{0 , 0 3 2}$ & $\mathbf{1 0}$ \\
\hline Teluk Dalam - Lolowau (Sta. 046+230) & $\mathbf{0 , 0 3 2}$ & $\mathbf{1 0}$ \\
\hline Lahusa - Teluk Dalam (Sta. 021+971) & $\mathbf{0 , 0 3 1}$ & $\mathbf{1 4}$ \\
\hline Kuta Buluh - Bts. Kota Sidikalang (Sta. 018+040) & $\mathbf{0 , 0 3 0}$ & $\mathbf{1 5}$ \\
\hline Kuta Buluh - Bts. Kota Sidikalang (Sta. 028+375) & $\mathbf{0 , 0 3 0}$ & $\mathbf{1 5}$ \\
\hline Batang Toru - Sp. Aek Rambe (Sta. 017+800) & $\mathbf{0 , 0 2 9}$ & $\mathbf{1 7}$ \\
\hline Sp. Aek Rambe - Singkuang (Sta. 050+800) & $\mathbf{0 , 0 2 9}$ & $\mathbf{1 7}$ \\
\hline Tetehosi - Lahusa (Sta. 033+800) & $\mathbf{0 , 0 2 9}$ & $\mathbf{1 7}$ \\
\hline Teluk Dalam - Lolowau (Sta. 050+830) & $\mathbf{0 , 0 2 9}$ & $\mathbf{1 7}$ \\
\hline Bts. Kota Medan - Bts. Kab. Karo (Sta 010+250) & $\mathbf{0 , 0 2 7}$ & $\mathbf{2 1}$ \\
\hline Merek - Bts. Kab. Dairi (Sta 099+100) & $\mathbf{0 , 0 2 7}$ & $\mathbf{2 1}$ \\
\hline Merek - Bts. Kab. Dairi (Sta 099+100) & $\mathbf{0 , 0 2 7}$ & $\mathbf{2 1}$ \\
\hline Jln. Kutacane - Bts. Kota Kabanjahe - Kuta Buluh (Sta. $050+450)$ & $\mathbf{0 , 0 2 7}$ & $\mathbf{2 1}$ \\
\hline Jln. Kutacane - Bts. Kota Kabanjahe - Kuta Buluh (Sta. 050+450) & $\mathbf{0 , 0 2 7}$ & $\mathbf{2 1}$ \\
\hline Bts. Kota Tarutung - Bts. Kab. Tapanuli Tengah (Sta. 030+400) & $\mathbf{0 , 0 2 7}$ & $\mathbf{2 1}$ \\
\hline Lahusa - Teluk Dalam (Sta. 017+000) & $\mathbf{0 , 0 2 7}$ & $\mathbf{2 1}$ \\
\hline Teluk Dalam - Lolowau (Sta. 049+680) & $\mathbf{0 , 0 2 7}$ & $\mathbf{2 1}$ \\
\hline
\end{tabular}




\begin{tabular}{lcc}
\hline \multicolumn{1}{c}{ Ruas } & $\begin{array}{c}\text { Nilai Bahaya } \\
\text { Longsor }\end{array}$ & Ranking \\
\hline Teluk Dalam - Lolowau (Sta. 061+810) & $\mathbf{0 , 0 2 7}$ & $\mathbf{2 1}$ \\
\hline Barus - Bts. Kota Sibolga (Sta. 010+515) & $\mathbf{0 , 0 2 6}$ & $\mathbf{3 0}$ \\
\hline Bts. Kota Tarutung - Bts. Kab. Tapanuli Tengah (Sta. 045+100) & $\mathbf{0 , 0 2 6}$ & $\mathbf{3 0}$ \\
\hline Bts. Kota Medan - Bts. Kab. Karo (Sta 021+950) & $\mathbf{0 , 0 2 2}$ & $\mathbf{3 2}$ \\
\hline Jln. Kutacane - Bts. Kota Kabanjahe - Kuta Buluh (Sta. 049+550) & $\mathbf{0 , 0 2 2}$ & $\mathbf{3 2}$ \\
\hline Kuta Buluh - Bts. Kota Sidikalang (Sta. 033+110) & $\mathbf{0 , 0 2 2}$ & $\mathbf{3 2}$ \\
\hline
\end{tabular}

4. Analisa Tingkat Prioritas Penanganan Jalan

Dalam menganalisis tingkat prioritas penanganan jalan, penelitian ini mengkombinasikan hasil perhitungan tingkat bahaya longsor dan ditambah dengan parameter rekayasa lereng dengan nilai indeks kriteria yang diperoleh dari Draft Pedoman Penilaian Tingkat Resiko Lereng Jalan yang dikeluarkan Kementrian Pekerjaan Umum dan Perumahan Rakyat pada tahun 2018 dan lalulintas harian ratarata. Dengan demikian akan diperoleh nilai kriteria tingkat perioritas penanganan jalan yang dapat dilihat pada Tabel 12 berikut.

Tabel 12

Nilai Kriteria Pada Alternatif Tingkat Prioritas Penanganan Jalan

\begin{tabular}{cllccc}
\hline No. & \multicolumn{1}{c}{ Ruas } & BL & DL & RL & LH \\
\hline 1 & $\begin{array}{l}\text { Bts. Kota Medan - Bts. Kab. Karo (Sta } \\
\text { 010+250) }\end{array}$ & 0,027 & 223,0 & -20 & 14278 \\
\hline 2 & $\begin{array}{l}\text { Bts. Kota Medan - Bts. Kab. Karo (Sta } \\
\text { 021+950) }\end{array}$ & 0,022 & 200,0 & -20 & 14278 \\
\hline 3 & Merek - Bts. Kab. Dairi (Sta 099+100) & 0,027 & 600,0 & 0 & 7233 \\
\hline 4 & Merek - Bts. Kab. Dairi (Sta 099+100) & 0,027 & 624,0 & 0 & 7233 \\
\hline 5 & Tiga Rungu - Tanjung Dolok (Sta 125+310) & 0,032 & 214,5 & 0 & 3881 \\
\hline 6 & $\begin{array}{l}\text { Jln. Kutacane - Bts. Kota Kabanjahe - Kuta } \\
\text { Buluh (Sta. 049+550) }\end{array}$ & 0,022 & 90,0 & 0 & 3153 \\
\hline 7 & $\begin{array}{l}\text { Jln. Kutacane - Bts. Kota Kabanjahe - Kuta } \\
\text { Buluh (Sta. 050+450) }\end{array}$ & 0,027 & 750,0 & 0 & 3135 \\
\hline 8 & $\begin{array}{l}\text { Jln. Kutacane - Bts. Kota Kabanjahe - Kuta } \\
\text { Buluh (Sta. 050+450) }\end{array}$ & 0,027 & 180,0 & 0 & 3135 \\
\hline 9 & $\begin{array}{l}\text { Kuta Buluh - Bts. Kota Sidikalang (Sta. } \\
\text { 018+040) }\end{array}$ & 0,030 & 345,0 & 0 & 2530 \\
\hline 10 & $\begin{array}{l}\text { Kuta Buluh - Bts. Kota Sidikalang (Sta. } \\
\text { 028+375) }\end{array}$ & 0,030 & 750,0 & 0 & 2530 \\
\hline 11 & $\begin{array}{l}\text { Kuta Buluh - Bts. Kota Sidikalang (Sta. } \\
\text { 033+110) }\end{array}$ & 0,022 & 940,0 & -10 & 2530 \\
\hline 12 & Barus - Bts. Kota Sibolga (Sta. 010+515) & 0,026 & 210,0 & -10 & 917 \\
\hline 13 & Rampa - Poriaha/Mungkur (Sta. 007+000) & 0,033 & 240,0 & 0 & 254 \\
\hline
\end{tabular}


Analisis Tingkat Bahaya Longsor pada Jalan Nasional untuk Prioritas Penanganan dengan Metode AHP: Studi Kasus Jalan pada Satker PJN III dan PJN IV

\begin{tabular}{|c|c|c|c|c|c|}
\hline No. & Ruas & BL & $\mathbf{D L}$ & $\mathbf{R L}$ & $\mathbf{L H}$ \\
\hline 14 & Rampa - Poriaha/Mungkur (Sta. 007+000) & 0,033 & 425,0 & 0 & 254 \\
\hline 15 & $\begin{array}{l}\text { Bts. Kota Tarutung - Bts. Kab. Tapanuli } \\
\text { Tengah (Sta. } 023+580)\end{array}$ & 0,033 & 215,0 & 0 & 1679 \\
\hline 16 & $\begin{array}{l}\text { Bts. Kota Tarutung - Bts. Kab. Tapanuli } \\
\text { Tengah (Sta. } 030+400)\end{array}$ & 0,027 & 150,0 & 0 & 1679 \\
\hline 17 & $\begin{array}{l}\text { Bts. Kota Tarutung - Bts. Kab. Tapanuli } \\
\text { Tengah (Sta. 032+680) }\end{array}$ & 0,033 & 130,0 & 0 & 1679 \\
\hline 18 & $\begin{array}{l}\text { Bts. Kota Tarutung - Bts. Kab. Tapanuli } \\
\text { Tengah (Sta. } 045+100)\end{array}$ & 0,026 & 180,0 & -10 & 1441 \\
\hline 19 & $\begin{array}{l}\text { Bts. Kab Tapanuli Utara - Bts. Kota Sibolga } \\
\text { (Sta. 020+980) }\end{array}$ & 0,035 & 800,0 & 0 & 1154 \\
\hline 20 & $\begin{array}{l}\text { Bts. Kab Tapanuli Utara - Bts. Kota Sibolga } \\
\text { (Sta. 020+980) }\end{array}$ & 0,035 & 525,0 & 0 & 1154 \\
\hline 21 & $\begin{array}{l}\text { Bts. Kab Tapanuli Utara - Bts. Kota Sibolga } \\
(\text { Sta. 021+260) }\end{array}$ & 0,035 & 348,0 & 0 & 1154 \\
\hline 22 & $\begin{array}{l}\text { Bts. Kab Tapanuli Utara - Bts. Kota Sibolga } \\
(\text { Sta. 021+260) }\end{array}$ & 0,035 & 285,0 & 0 & 1154 \\
\hline 23 & $\begin{array}{l}\text { Batang Toru }- \text { Sp. Aek Rambe (Sta. } \\
017+800)\end{array}$ & 0,029 & 224,0 & 0 & 662 \\
\hline 24 & Sp. Aek Rambe - Singkuang (Sta. 050+800) & 0,029 & 19,5 & 0 & 662 \\
\hline 25 & Tetehosi - Lahusa (Sta. 033+800) & 0,029 & 49,5 & -10 & 854 \\
\hline 26 & Lahusa - Teluk Dalam (Sta. 017+000) & 0,027 & 112,0 & 0 & 1678 \\
\hline 27 & Lahusa - Teluk Dalam (Sta. 021+971) & 0,031 & 120,0 & -10 & 1678 \\
\hline 28 & Teluk Dalam - Lolowau (Sta. 036+580) & 0,032 & 112,5 & -20 & 1384 \\
\hline 29 & Teluk Dalam - Lolowau (Sta. 043+180) & 0,032 & 40,0 & 0 & 1384 \\
\hline 30 & Teluk Dalam - Lolowau (Sta. 046+230) & 0,032 & 69,0 & 0 & 1384 \\
\hline 31 & Teluk Dalam - Lolowau (Sta. 049+680) & 0,027 & 100,0 & 0 & 1384 \\
\hline 32 & Teluk Dalam - Lolowau (Sta. 050+830) & 0,029 & 175,0 & 0 & 1384 \\
\hline 33 & Teluk Dalam - Lolowau (Sta. 052+780) & 0,035 & 140,0 & 0 & 1384 \\
\hline \multirow[t]{2}{*}{34} & Teluk Dalam - Lolowau (Sta. 061+810) & 0,027 & 88,0 & -20 & 1384 \\
\hline & Jumlah & 1,000 & 9674,0 & -130 & 91657 \\
\hline
\end{tabular}

Dalam menentukan tingkat prioritisasi penanganan jalan pada masing-masing titik longsor, maka dilakukan perhitungan perkalian nilai eigen alternatif dengan nilai bobot kriteria pada setiap kriteria yang bersesuaian. Nilai eigen alternatif diperoleh dengan melakukan normalisasi pada setiap nilai kriteria pada alternatif dengan kriteria yang bersesuaian. Untuk mendapatkan tingkat prioritisasi penanganan longsoran jalan yang terjadi pada masing-masing ruas dilakukan perkalian nilai eigen alternatif dengan bobot kriteria. Hasil perhitungan tingkat prioritas penanganan longsoran jalan dapat dilihat pada Tabel 13. 
Tabel 13

Hasil Perhitungan Tingkat Prioritas Longsoran Jalan

\begin{tabular}{|c|c|c|c|c|c|c|}
\hline No. & Ruas & $\begin{array}{c}B L \\
(0,362)\end{array}$ & $\begin{array}{c}D L \\
(0,326)\end{array}$ & $\begin{array}{c}R L \\
(0,148)\end{array}$ & $\begin{array}{c}L H \\
(0,163)\end{array}$ & Hasil \\
\hline 1 & $\begin{array}{l}\text { Bts. Kota Medan - Bts. Kab. Karo } \\
\text { (Sta 010+250) }\end{array}$ & 0,010 & 0,008 & $-0,023$ & 0,025 & $\mathbf{0 , 0 2 0}$ \\
\hline 2 & $\begin{array}{l}\text { Bts. Kota Medan - Bts. Kab. Karo } \\
(\text { Sta } 021+950)\end{array}$ & 0,008 & 0,007 & $-0,023$ & 0,025 & $\mathbf{0 , 0 1 7}$ \\
\hline 3 & $\begin{array}{l}\text { Merek }- \text { Bts. Kab. Dairi } \\
\text { 099+100) }\end{array}$ & 0,010 & 0,020 & 0,000 & 0,013 & 0,043 \\
\hline 4 & $\begin{array}{l}\text { Merek - Bts. Kab. Dairi } \\
099+100)\end{array}$ & 0,010 & 0,021 & 0,000 & 0,013 & 0,044 \\
\hline 5 & $\begin{array}{l}\text { Tiga Rungu - Tanjung Dolok (Sta } \\
125+310)\end{array}$ & 0,012 & 0,007 & 0,000 & 0,007 & 0,026 \\
\hline 6 & $\begin{array}{l}\text { Jln. Kutacane - Bts. Kota Kabanjahe - } \\
\text { Kuta Buluh (Sta. 049+550) }\end{array}$ & 0,008 & 0,003 & 0,000 & 0,006 & $\mathbf{0 , 0 1 7}$ \\
\hline 7 & $\begin{array}{l}\text { Jln. Kutacane - Bts. Kota Kabanjahe - } \\
\text { Kuta Buluh (Sta. 050+450) }\end{array}$ & 0,010 & 0,025 & 0,000 & 0,006 & 0,041 \\
\hline 8 & $\begin{array}{l}\text { Jln. Kutacane - Bts. Kota Kabanjahe - } \\
\text { Kuta Buluh (Sta. 050+450) }\end{array}$ & 0,010 & 0,006 & 0,000 & 0,006 & $\mathbf{0 , 0 2 1}$ \\
\hline 9 & $\begin{array}{l}\text { Kuta Buluh - Bts. Kota Sidikalang } \\
\text { (Sta. 018+040) }\end{array}$ & 0,011 & 0,012 & 0,000 & 0,005 & $\mathbf{0 , 0 2 7}$ \\
\hline 10 & $\begin{array}{l}\text { Kuta Buluh - Bts. Kota Sidikalang } \\
\text { (Sta. 028+375) }\end{array}$ & 0,011 & 0,025 & 0,000 & 0,005 & 0,041 \\
\hline 11 & $\begin{array}{l}\text { Kuta Buluh - Bts. Kota Sidikalang } \\
\text { (Sta. 033+110) }\end{array}$ & 0,008 & 0,032 & $-0,011$ & 0,005 & $\mathbf{0 , 0 3 3}$ \\
\hline 12 & $\begin{array}{l}\text { Barus - Bts. Kota Sibolga (Sta. } \\
010+515)\end{array}$ & 0,009 & 0,007 & $-0,011$ & 0,002 & $\mathbf{0 , 0 0 7}$ \\
\hline 13 & $\begin{array}{l}\text { Rampa }- \text { Poriaha/Mungkur (Sta. } \\
007+000)\end{array}$ & 0,012 & 0,008 & 0,000 & 0,000 & $\mathbf{0 , 0 2 0}$ \\
\hline 14 & $\begin{array}{l}\text { Rampa }- \text { Poriaha/Mungkur } \quad \text { (Sta. } \\
007+000)\end{array}$ & 0,012 & 0,014 & 0,000 & 0,000 & $\mathbf{0 , 0 2 7}$ \\
\hline 15 & $\begin{array}{l}\text { Bts. Kota Tarutung }- \text { Bts. Kab. } \\
\text { Tapanuli Tengah }(\text { Sta. } 023+580)\end{array}$ & 0,012 & 0,007 & 0,000 & 0,003 & $\mathbf{0 , 0 2 2}$ \\
\hline 16 & $\begin{array}{l}\text { Bts. Kota Tarutung }- \text { Bts. Kab. } \\
\text { Tapanuli Tengah }(\text { Sta. } 030+400)\end{array}$ & 0,010 & 0,005 & 0,000 & 0,003 & $\mathbf{0 , 0 1 8}$ \\
\hline 17 & $\begin{array}{l}\text { Bts. Kota Tarutung }- \text { Bts. Kab. } \\
\text { Tapanuli Tengah }(\text { Sta. } 032+680)\end{array}$ & 0,012 & 0,004 & 0,000 & 0,003 & $\mathbf{0 , 0 1 9}$ \\
\hline 18 & $\begin{array}{l}\text { Bts. Kota Tarutung }- \text { Bts. Kab. } \\
\text { Tapanuli Tengah }(\text { Sta. } 045+100)\end{array}$ & 0,009 & 0,006 & $-0,011$ & 0,003 & $\mathbf{0 , 0 0 7}$ \\
\hline 19 & $\begin{array}{l}\text { Bts. Kab Tapanuli Utara - Bts. Kota } \\
\text { Sibolga (Sta. 020+980) }\end{array}$ & 0,013 & 0,027 & 0,000 & 0,002 & 0,042 \\
\hline 20 & $\begin{array}{l}\text { Bts. Kab Tapanuli Utara - Bts. Kota } \\
\text { Sibolga (Sta. 020+980) }\end{array}$ & 0,013 & 0,018 & 0,000 & 0,002 & $\mathbf{0 , 0 3 2}$ \\
\hline 21 & $\begin{array}{l}\text { Bts. Kab Tapanuli Utara - Bts. Kota } \\
\text { Sibolga (Sta. } 021+260)\end{array}$ & 0,013 & 0,012 & 0,000 & 0,002 & 0,026 \\
\hline 22 & Bts. Kab Tapanuli Utara - Bts. Kota & 0,013 & 0,010 & 0,000 & 0,002 & $\mathbf{0 , 0 2 4}$ \\
\hline
\end{tabular}


Analisis Tingkat Bahaya Longsor pada Jalan Nasional untuk Prioritas Penanganan dengan Metode AHP: Studi Kasus Jalan pada Satker PJN III dan PJN IV

\begin{tabular}{|c|c|c|c|c|c|c|}
\hline No. & Ruas & $\begin{array}{c}B L \\
(0,362)\end{array}$ & $\begin{array}{c}D L \\
(0,326)\end{array}$ & $\begin{array}{c}R L \\
(0,148)\end{array}$ & $\begin{array}{c}\mathrm{LH} \\
(0,163)\end{array}$ & Hasil \\
\hline & Sibolga (Sta. 021+260) & & & & & \\
\hline 23 & $\begin{array}{l}\text { Batang Toru - Sp. Aek Rambe (Sta. } \\
017+800)\end{array}$ & 0,011 & 0,008 & 0,000 & 0,001 & $\mathbf{0 , 0 1 9}$ \\
\hline 24 & $\begin{array}{l}\text { Sp. Aek Rambe - Singkuang (Sta. } \\
050+800)\end{array}$ & 0,011 & 0,001 & 0,000 & 0,001 & $\mathbf{0 , 0 1 2}$ \\
\hline 25 & Tetehosi - Lahusa (Sta. 033+800) & 0,011 & 0,002 & $-0,011$ & 0,002 & 0,002 \\
\hline 26 & Lahusa - Teluk Dalam (Sta. 017+000) & 0,010 & 0,004 & 0,000 & 0,003 & $\mathbf{0 , 0 1 7}$ \\
\hline 27 & Lahusa - Teluk Dalam (Sta. 021+971) & 0,011 & 0,004 & $-0,011$ & 0,003 & 0,007 \\
\hline 28 & $\begin{array}{l}\text { Teluk Dalam }- \text { Lolowau } \\
036+580)\end{array}$ & 0,012 & 0,004 & $-0,023$ & 0,002 & $\overline{0,}$ \\
\hline 29 & $\begin{array}{l}\text { Teluk Dalam }- \text { Lolowau } \\
043+180)\end{array}$ & 0,012 & 0,001 & 0,000 & 0,002 & $\mathbf{0 , 0 1 5}$ \\
\hline 30 & $\begin{array}{l}\text { Teluk Dalam }- \text { Lolowau (Sta. } \\
046+230)\end{array}$ & 0,012 & 0,002 & 0,000 & 0,002 & 0,016 \\
\hline 31 & $\begin{array}{l}\text { Teluk Dalam }- \text { Lolowau } \\
049+680)\end{array}$ & 0,010 & 0,003 & 0,000 & 0,002 & 0,016 \\
\hline 32 & $\begin{array}{l}\text { Teluk Dalam }- \text { Lolowau } \\
050+830)\end{array}$ & 0,011 & 0,006 & 0,000 & 0,002 & 0,019 \\
\hline 33 & $\begin{array}{l}\text { Teluk Dalam }- \text { Lolowau (Sta. } \\
052+780)\end{array}$ & 0,013 & 0,005 & 0,000 & 0,002 & $\mathbf{0 , 0 2 0}$ \\
\hline 34 & $\begin{array}{l}\text { Teluk Dalam }- \text { Lolowau } \text { (Sta. } \\
061+810)\end{array}$ & 0,010 & 0,003 & $-0,023$ & 0,002 & $\overline{0}$ \\
\hline
\end{tabular}

Dari hasil perhitungan tingkat bahaya longsor maka dapat dilakukan perangkingan seperti pada Tabel 14 yang akan menjelaskan tingkat prioritas penanganan pada masingmasing ruas jalan.

Tabel 14

Rekapitulasi Tingkat Prioritas Penanganan Longsoran Jalan

\begin{tabular}{lcc}
\hline \multicolumn{1}{c}{ Ruas } & $\begin{array}{c}\text { Nilai } \\
\text { Prioritas }\end{array}$ & Ranking \\
\hline Merek - Bts. Kab. Dairi (Sta 099+100) & $\mathbf{0 , 0 4 4}$ & $\mathbf{1}$ \\
\hline Merek - Bts. Kab. Dairi (Sta 099+100) & $\mathbf{0 , 0 4 3}$ & $\mathbf{2}$ \\
\hline Bts. Kab Tapanuli Utara - Bts. Kota Sibolga (Sta. 020+980) & $\mathbf{0 , 0 4 2}$ & $\mathbf{3}$ \\
\hline Jln. Kutacane - Bts. Kota Kabanjahe - Kuta Buluh & (Sta. & $\mathbf{4}$ \\
050+450) & $\mathbf{0 , 0 4 1}$ & \\
\hline Kuta Buluh - Bts. Kota Sidikalang (Sta. 028+375) & $\mathbf{0 , 0 4 1}$ & $\mathbf{4}$ \\
\hline Kuta Buluh - Bts. Kota Sidikalang (Sta. 033+110) & $\mathbf{0 , 0 3 3}$ & $\mathbf{6}$ \\
\hline Bts. Kab Tapanuli Utara - Bts. Kota Sibolga (Sta. 020+980) & $\mathbf{0 , 0 3 2}$ & $\mathbf{7}$ \\
\hline Kuta Buluh - Bts. Kota Sidikalang (Sta. 018+040) & $\mathbf{0 , 0 2 7}$ & $\mathbf{8}$ \\
\hline Rampa - Poriaha/Mungkur (Sta. 007+000) & $\mathbf{0 , 0 2 7}$ & $\mathbf{8}$ \\
\hline Bts. Kab Tapanuli Utara - Bts. Kota Sibolga (Sta. 021+260) & $\mathbf{0 , 0 2 6}$ & $\mathbf{1 0}$ \\
\hline Tiga Rungu - Tanjung Dolok (Sta 125+310) & $\mathbf{0 , 0 2 6}$ & $\mathbf{1 0}$ \\
\hline Bts. Kab Tapanuli Utara - Bts. Kota Sibolga (Sta. 021+260) & $\mathbf{0 , 0 2 4}$ & $\mathbf{1 2}$ \\
\hline Bts. Kota Tarutung - Bts. Kab. Tapanuli Tengah (Sta. 023+580) & $\mathbf{0 , 0 2 2}$ & $\mathbf{1 3}$ \\
\hline
\end{tabular}




\begin{tabular}{lcc}
\hline \multicolumn{1}{c}{ Ruas } & $\begin{array}{c}\text { Nilai } \\
\text { Prioritas }\end{array}$ & Ranking \\
\hline Jln. Kutacane - Bts. Kota Kabanjahe - Kuta & Buluh $($ Sta. & $\mathbf{1 4}$ \\
050+450) & $\mathbf{0 , 0 2 1}$ & \\
\hline Bts. Kota Medan - Bts. Kab. Karo (Sta 010+250) & $\mathbf{0 , 0 2 0}$ & $\mathbf{1 5}$ \\
\hline Rampa - Poriaha/Mungkur (Sta. 007+000) & $\mathbf{0 , 0 2 0}$ & $\mathbf{1 5}$ \\
\hline Teluk Dalam - Lolowau (Sta. 052+780) & $\mathbf{0 , 0 2 0}$ & $\mathbf{1 5}$ \\
\hline Bts. Kota Tarutung - Bts. Kab. Tapanuli Tengah (Sta. 032+680) & $\mathbf{0 , 0 1 9}$ & $\mathbf{1 8}$ \\
\hline Batang Toru - Sp. Aek Rambe (Sta. 017+800) & $\mathbf{0 , 0 1 9}$ & $\mathbf{1 8}$ \\
\hline Teluk Dalam - Lolowau (Sta. 050+830) & $\mathbf{0 , 0 1 9}$ & $\mathbf{1 8}$ \\
\hline Bts. Kota Tarutung - Bts. Kab. Tapanuli Tengah (Sta. 030+400) & $\mathbf{0 , 0 1 8}$ & $\mathbf{2 1}$ \\
\hline Bts. Kota Medan - Bts. Kab. Karo (Sta 021+950) & $\mathbf{0 , 0 1 7}$ & $\mathbf{2 2}$ \\
\hline Jln. Kutacane - Bts. Kota Kabanjahe - Kuta & Buluh & $\mathbf{2 2}$ \\
049+550) & $\mathbf{0 , 0 1 7}$ & \\
\hline Lahusa - Teluk Dalam (Sta. 017+000) & $\mathbf{0 , 0 1 7}$ & $\mathbf{2 2}$ \\
\hline Teluk Dalam - Lolowau (Sta. 046+230) & $\mathbf{0 , 0 1 6}$ & $\mathbf{2 5}$ \\
\hline Teluk Dalam - Lolowau (Sta. 049+680) & $\mathbf{0 , 0 1 6}$ & $\mathbf{2 5}$ \\
\hline Teluk Dalam - Lolowau (Sta. 043+180) & $\mathbf{0 , 0 1 5}$ & $\mathbf{2 7}$ \\
\hline Sp. Aek Rambe - Singkuang (Sta. 050+800) & $\mathbf{0 , 0 1 2}$ & $\mathbf{2 8}$ \\
\hline Barus - Bts. Kota Sibolga (Sta. 010+515) & $\mathbf{0 , 0 0 7}$ & $\mathbf{2 9}$ \\
\hline Bts. Kota Tarutung - Bts. Kab. Tapanuli Tengah (Sta. 045+100) & $\mathbf{0 , 0 0 7}$ & $\mathbf{2 9}$ \\
\hline Lahusa - Teluk Dalam (Sta. 021+971) & $\mathbf{0 , 0 0 7}$ & $\mathbf{2 9}$ \\
\hline Tetehosi - Lahusa (Sta. 033+800) & $\mathbf{0 , 0 0 2}$ & $\mathbf{3 2}$ \\
\hline Teluk Dalam - Lolowau (Sta. 036+580) & $\mathbf{- 0 , 0 0 5}$ & $\mathbf{3 3}$ \\
\hline Teluk Dalam - Lolowau (Sta. 061+810) & $\mathbf{- 0 , 0 0 8}$ & $\mathbf{3 4}$ \\
\hline
\end{tabular}

\section{Kesimpulan}

Berdasarkan hasil pembahasan dan analisa yang telah dilakukan penelitian ini, maka dapat disimpulkan beberapa hal sebagai berikut: (1.) Dengan menggunakan metode AHP tingkat bahaya longsor sangat dipengaruhi oleh kemiringan tanah dengan nilai bobot sebesar 0,35 , kemudian dipengaruhi berturut-turut oleh curah hujan $(0,26)$, tutupan lahan $(0,19)$, tanah dasar $(0,12)$ dan kondisi drainase $(0,08)$. (2.) Perhitungan metode AHP untuk tingkat prioritas penanganan longsoran besar dipengaruhi oleh bahaya longsor sebesar 0,362 , diikuti dengan dimensi longsor $(0,326)$, lalulintas harian $(0,163)$ dan rekayasa lereng $(0,148)$. (3.) Dengan menggunakan metode AHP, ruas jalan yang memiliki tingkat bahaya longsor paling tinggi adalah ruas Jalan Bts. Kab Tapanuli Utara - Bts. Kota Sibolga (Sta. 020+980) dan $($ Sta. 021+260) serta Teluk Dalam Lolowau (Sta. 052+780) dengan nilai sebesar 0,035. Sedangkan ruas jalan yang memiliki tingkat bahaya longsor paling rendah adalah ruas Bts. Kota Medan - Bts. Kab. Karo (Sta 021+950), Jln. Kutacane - Bts. Kota Kabanjahe - Kuta Buluh (Sta. 049+550) dan Kuta Buluh - Bts. Kota Sidikalang (Sta. 033+110) dengan nilai 0,022. (4.) Untuk tingkat prioritas penanganan longsoran jalan dengan menggunakan metode AHP, ruas Jalan Merek - Bts. Kab. Dairi (Sta 099+100) memiliki tingkat prioritas paling tinggi dengan nilai 0,044 . Sedangkan ruas jalan yang memiliki tingkat prioritas penanganan 
Analisis Tingkat Bahaya Longsor pada Jalan Nasional untuk Prioritas Penanganan dengan Metode AHP: Studi Kasus Jalan pada Satker PJN III dan PJN IV

longsoran jalan paling rendah adalah ruas Jalan Teluk Dalam - Lolowau (Sta. 061+810) dengan nilai $-0,008$.

\section{BIBLIOGRAFI}

Damanik, Klaus J. A. (2019). Meningkatkan Produksi Bawang Merah Melalui Pendekatan Kesesuaian Lahan Dan Curah Hujan Di Provinsi Sumatera Utara. Universitas Medan Area.Google Scholar

Fasa, Rd Zaky Miftahul. (2019). Resiliensi keluarga korban bencana longsor di Kecamatan Cimenyan Kabupaten Bandung. Jurnal Mimbar Kesejahteraan Sosial, 2(1). Google Scholar

Fatmawati, Kiki, Windarto, Agus Perdana, Solikhun, Solikhun, \& Lubis, Muhammad Ridwan. (2017). Analisa Spk Dengan Metode Ahp Dalam Menentukan Faktor Konsumen Dalam Melakukan Kredit Barang. KOMIK (Konferensi Nasional Teknologi Informasi Dan Komputer), 1(1). Google Scholar

Harefa, Eko Krisman, Ginting, Daniel, Sitorus, Mido Ester J., \& Nababan, Donal. (2021). Pengaruh Perilaku Tenaga Kesehatan Terhadap Kesiapsiagaan Bencana Di Kabupaten Nias Utara Tahun 2021. Prepotif: Jurnal Kesehatan Masyarakat, 5(2), 1152-1158. Google Scholar

Hasan, Muhammad, Fahmi, Ade Ismail, Siregar, Nurhasana, Musyadad, Vina Febiani, Sakirman, Sakirman, Subakti, Hani, \& Walukow, Devy Stany. (2021). Pengelolaan Lingkungan Belajar. Yayasan Kita Menulis. Google Scholar

Jagad, Satrio Tunggul Satoto, Mulyono, Agus Taufik, \& Santosa, Wimpy. (2020). Penyebab Badan Jalan Nasional Ambles Di Provinsi Jawa Barat. Jurnal HPJI (Himpunan Pengembangan Jalan Indonesia), 6(2), 151-164. Google Scholar

Julita, Ratna. (2016). Pemilihan Teknologi Pembangunan Drainase dengan Metode AHP. Google Scholar

Lasera, M., Mudin, Y., Rusydi, M. H. (2016). Determination Of Potential Landslide Area Using Analyticalal Hierarchy Process (AHP) Method In The District Kulawi, Sigi Regency. Journal of Natural Sciene, 5(3), 258-267.

Lestiani, Melia Eka. (2018). Faktor-faktor dominan promosi yang mempengaruhi motivasi konsumen dalam membeli suatu produk dengan menggunakan metode AHP. Jurnal Industri Elektro Dan Penerbangan, 1(1). Google Scholar

Mujiastuti, Rully, Meilina, Popy, \& Pramudiaji, Afridhon Iwan. (2017). Penggunaan Metode AHP dalam Menentukan Individual Development Plan untuk Mengukur Kompetensi Teknis Pekerja. JUST IT: Jurnal Sistem Informasi, Teknologi Informasi Dan Komputer, 7(2), 1-10. Google Scholar 
Nur, Oscar Fithrah, \& NIP, M. T. (2007). Analisis Resiko Kelongsoran Pada Lokasi Di Sekitar Perkantoran Walikota Bukittinggi. Google Scholar

Putra, Hendri Pitrio, \& Triyono, Sulis. (2018). Critical Discourse Analysis on Kompas. com News:'Gerakan\# 2019GantiPresiden'. LEKSEMA: Jurnal Bahasa Dan Sastra, 3(2), 113-121. Google Scholar

Rianto, Bayu. (2016). Sistem Pendukung Keputusan Penerimaan Karyawan Menggunakan Metode Analytical Hierarchy Process (AHP) Studi Kasus: RB. Nilam Sari Tembilahan. Riau Journal Of Computer Science, 2(2), 29-38. Google Scholar

Setiawan, Arifin, Ananto, Wiedo, \& Soehartanto, Totok. (2020). Implementasi Metode Analytic Hierarchy Process dalam Pemilihan Radar Udara 3D. Rekayasa, 13(1), 49-54. Google Scholar

Srianty, Joly, Isya, Muhammad, \& Anggraini, Renni. (2017). Analisis Kondisi Kemantapan Jalan Dengan Lalu Lintas Harian Rata-Rata Pada Jalan Arteri Sekunder. Jurnal Teknik Sipil, 1(1), 99-110. Google Scholar

Sulamet-Ariobimo, R. D., Santoso, J. R., Fadhlan, M., Yasin, T., Sukarnoto, T., Mujalis, Y., \& Oktaviano, Y. (2020). The effects of austenitizing process to mechanical properties of thin wall ductile iron connecting rod. AIP Conference Proceedings, 2262(1), 60006. AIP Publishing LLC. Google Scholar

Udiana, I. Made, Saudale, Andre R., \& Pah, Jusuf J. S. (2014). Analisa Faktor Penyebab Kerusakan Jalan (Studi Kasus Ruas Jalan WJ Lalamentik dan Ruas Jalan Gor Flobamora). Jurnal Teknik Sipil, 3(1), 13-18. Google Scholar

\section{Copyright holder:}

Maulidi Al Kahfi (2021)

First publication right:

Syntax Idea

This article is licensed under:

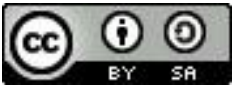

